UNIVERSIDADE DE SÃO PAULO

FCF/FEA/FSP/USP

PROGRAMA DE PÓS GRADUAÇÃO INTERUNIDADES

EM NUTRIÇÃO HUMANA APLICADA - PRONUT

ÁREA DE NUTRIÇÃO

\title{
IMPACTO DAS ALEGAÇÕES RELATIVAS AO GLÚTEN SOBRE AS ESCOLHAS DOS CONSUMIDORES
}

TAINÁ FERNANDES DRUB

DISSERTAÇÃO PARA OBTENÇÃO DO TÍTULO DE MESTRE

ORIENTADORA: PROFA. DRA. DENISE CAVALLINI CYRILLO

SÃO PAULO

2019 
UNIVERSIDADE DE SÃO PAULO

FCF/FEA/FSP/USP

PROGRAMA DE PÓS GRADUAÇÃO INTERUNIDADES

EM NUTRIÇÃO HUMANA APLICADA - PRONUT

ÁREA DE NUTRIÇÃO

\title{
IMPACTO DAS ALEGAÇÕES RELATIVAS AO GLÚTEN SOBRE AS ESCOLHAS DOS CONSUMIDORES
}

\author{
TAINÁ FERNANDES DRUB
}

Versão corrigida da Dissertação conforme resolução CoPGr 6018

\begin{abstract}
Dissertação da aluna Tainá Fernandes Drub para obtenção do Título de Mestre, vinculada ao Programa de Pós-Graduação Interunidades em Nutrição Humana Aplicada (PRONUT/USP), orientada pela Profa. Dra. Denise Cavallini Cyrillo da Faculdade de Economia, Administração e Contabilidade da USP.
\end{abstract}

ORIENTADORA: PROFA. DRA. DENISE CAVALLINI CYRILLO

SÃO PAULO 
Autorizo a reprodução e divulgação total ou parcial deste trabalho, por qualquer meio convencional ou eletronico, para fins de estudo e pesquisa, desde que citada a fonte.

Ficha Catalográfica

Elaborada pela Divisão de Biblioteca e

Documentação do Conjunto das Quimicas da USP.

Bibliotecária responsável pela orientação de catalogação da publicação: Marlene Aparecida Vieira - CRB - 8/5562

Drub, Tainá Fernandes

D794i Impacto das alegações relativas ao glúten sobre as escolhas dos consumidores. / Tainá Fernandes Drub. -- São Paulo, 2019. $92 \mathrm{p}$.

Dissertação (mestrado) - Faculdade de Ciências Farmacêuticas da USP. Faculdade de Economia, Administração e Contabilidade da USP. Faculdade de Saúde Pública da USP. Curso Interunidades em Nutrição Humana Aplicada.

Orientador: Cyrillo, Denise Cavallini

1. Nutrição aplicada: Ciência dos alimentos. 2. Rotulagem de alimentos: Ciência dos alimentos. I. T. II. Cyrillo, Denise Cavallini, orientador.

$641.1 \quad \mathrm{CDD}$ 
IMPACTO DAS ALEGAÇÕES RELATIVAS AO GLÚTEN SOBRE AS ESCOLHAS DOS CONSUMIDORES

\author{
COMISSÃO JULGADORA DA \\ DISSERTAÇÃO PARA OBTENÇÃO DO TÍTULO DE MESTRE
}

PROFA. DRA. DENISE CAVALLINI CYRILLO

ORIENTADORA/PRESIDENTE

$1^{\circ}$ Examinador

$2^{\circ}$ Examinador

$3^{\circ}$ Examinador

$4^{\circ}$ Examinador

São Paulo, de de 2019 
Ao meu maior exemplo de amor persistência e dedicação:

Marisa Drub, minha mãe. 


\section{AGRADECIMENTOS}

À Deus, o Senhor de todas as coisas e àquele a quem sigo fielmente para trilhar o melhor caminho com amor.

À minha mãe, Marisa Drub, que está do meu lado em qualquer circunstância, me dando todo o amparo necessário, e que me ensina que nada nesta vida pode ser conquistado se não houver amor e dedicação.

À minha amada família, meu irmão, minha avó e minha tia, que me ensinaram a vencer todas as lutas com amor, fé e honestidade, e o Fred e a Nina que me ensinam o amor mais puro que existe na face da Terra.

Ao Victor Arthur, que trilha junto comigo um caminho de esperança e amor, e constrói a cada dia um companheirismo único e abençoado.

À minha querida orientadora, Profa. Dra. Denise Cavallini Cyrillo, por ter me concedido a sublime oportunidade de iniciar um passo para uma longa jornada na minha carreira, me acompanhando da forma mais gentil e carinhosa.

Aos nobres conselhos das professoras: Profa. Dra. Flávia Mori Sarti; Profa. Dra. Basília Maria Baptista Aguirre e Profa. Dra. Eliana Bistriche Giuntini, participantes da banca de qualificação.

Aos meus amigos que são uma riqueza imensurável e me apoiaram dia após dia para escolha deste caminho, dentre estes, ressalto alguns deles: Pedro Calocci, Raquel Campos, Ana Carolina Solera e Giulianna Sacino. 
Ao Prof. Dr. Thomas Prates Ong, pelo trabalho de um ano no Programa de Aperfeiçoamento ao Ensino nas disciplinas de Nutrição Humana e Nutrigenômica que me possibilitou ter uma visão da docência como a arte de entender o próximo em harmonia com o papel acadêmico.

Aos participantes da pesquisa, que doaram um pouco do seu tempo e do seu conhecimento para permitirem que esse estudo acontecesse.

Aos supermercados, que com gentileza me dispuseram um espaço e tempo dos seus clientes para participarem da pesquisa, são eles: Tateno (Vila Mariana), Hortisabor (Vila Mariana), Hortifruti União (Mirandópolis), Mundo Verde (Shopping Metrô Santa Cruz).

Aos grupos de celíacos que autorizaram a divulgação da pesquisa com o intuito de melhorar cada vez mais a informação sobre os produtos sem glúten (FENACELBRA; Rio Sem Glúten; ACELBRA SP; ACELBRA SC; ACELBRA RJ; Doença Celíaca - Brasil; Celíacos do Brasil).

À CAPES - Coordenação de Aperfeiçoamento de Pessoal de Nível Superior - pelo apoio financeiro. 
“AQUELE QUE COMEÇOU A BOA OBRA, A APERFEIÇOARÁ” (FILIPENSES 1:6) 


\section{RESUMO}

DRUB, T. F. Impacto das alegações relativas ao glúten sobre as escolhas dos consumidores. 2019. 92f. Dissertação (Mestrado) - Faculdade de Ciências Farmacêuticas, Faculdade de Economia, Administração e Contabilidade e Faculdade de Saúde Pública, Universidade de São Paulo, São Paulo, 2019.

Os produtos sem glúten vêm aumentando sua participação no mercado atual, direcionados a uma população com restrição alimentar, como no caso da doença celíaca. Para segurança destes consumidores, foi criada uma legislação tratando das informações contidas nos rótulos, como as alegações relativas à presença ou não de glúten nos produtos. No entanto, a alegação "NÃO CONTÉM GLÚTEN" é informação útil à indústria, no contexto de seu marketing nutricional e, assim, como um elemento de sua estratégia de concorrência. O objetivo dessa pesquisa foi avaliar o impacto do marketing nutricional de alimentos sem glúten industrializados na rotulagem, sobre as escolhas alimentares de consumidores leigos, sem doença celíaca. Por meio de uma pesquisa qualitativa descritiva utilizando o método do Discurso do Sujeito Coletivo, concluiu-se que mais de $50 \%$ dos participantes recrutados seguem uma dieta livre de glúten motivados pela crença de ser saudável e auxiliar na manutenção do peso corpóreo. Estas motivações contrapõem-se à análise dos rótulos de produtos sem glúten industrializados que, apesar de estarem em conformidade com a LF 10.674/2003, são produtos, em sua maioria, ricos em carboidratos, com elevada densidade energética e sódio, cujos preços variam de 2 a 16 vezes mais que os produtos tradicionais similares. Grande parte das informações obtidas pelos participantes advém de meios virtuais como a internet e redes sociais, que promovem informação equivocada por meio de um marketing nutricional virtual que se aproveita de mitos envolvendo o glúten. Com os resultados dessa pesquisa, propõe-se o aumento de ações que visem informar corretamente a população brasileira sobre o assunto e o aprimoramento da legislação vigente determinando especificamente o local e o formato da informação básica sobre o glúten na rotulagem.

Palavras-chave: produtos sem glúten; marketing nutricional virtual; rotulagem de alimentos. 


\begin{abstract}
DRUB, T. F. Impact of gluten claims on consumers choices. 2019. 92f. Dissertação (Mestrado) - Faculdade de Ciências Farmacêuticas, Faculdade de Economia, Administração e Contabilidade e Faculdade de Saúde Pública, Universidade de São Paulo, São Paulo, 2019.
\end{abstract}

Gluten-free products are increasing their share in the current market, targeting a population with food restriction, as in the case of celiac disease. For the safety of these consumers, legislation has been introduced dealing with information on labels such as claims regarding the presence or absence of gluten in products. However, the "GLUTEN FREE" claim is useful information to the industry in the context of its nutritional marketing and thus as an element of its competitive strategy. The objective of this research was to evaluate the impact of nutritional marketing of gluten-free foods by labeling processing on the food choices of lay consumers without celiac disease. Through a descriptive qualitative research using the Collective Subject Discourse method, it was concluded that more than $50 \%$ of the recruited participants follow a gluten-free diet motivated by the belief of being healthy and assisting in maintaining body weight. These motivations contrast with the analysis of processed gluten-free product labels which, while complying with LF 10.674/2003, are mostly carbohydrate-rich, high-calorie and sodium products, the prices of which vary. 2 to 16 times more than similar traditional products. Much of the information obtained by participants comes from virtual media such as the internet and social networks, which promote misinformation through virtual nutritional marketing that takes advantage of gluten myths. With the results of this research, it is proposed to increase actions aimed at correctly informing the Brazilian population about the subject and the improvement of current legislation, specifically determining the location and format of basic information on gluten in the labeling.

Keywords: gluten free products; virtual nutritional marketing; food labeling. 


\section{SUMÁRIO}

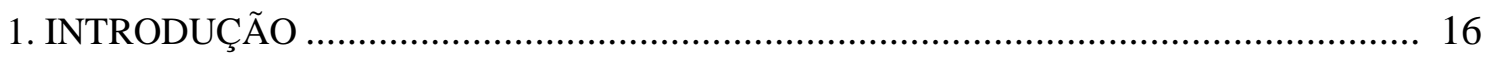

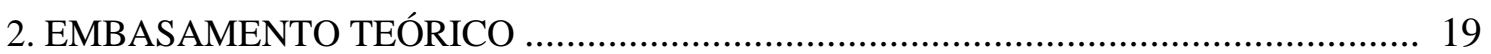

2.1 Doença celíaca e outras desordens relacionadas ao glúten ............................................ 19

2.2 Especificidades sobre a presença de glúten nos alimentos.............................................. 21

2.3 Qualidade nutricional dos produtos sem glúten ............................................................. 22

2.4 Marketing nutricional e os produtos sem glúten ............................................................. 24

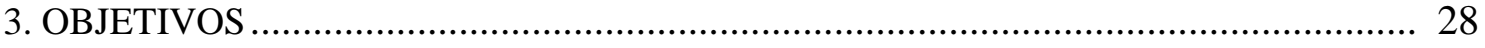

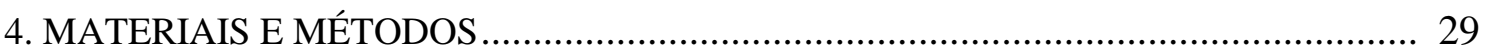

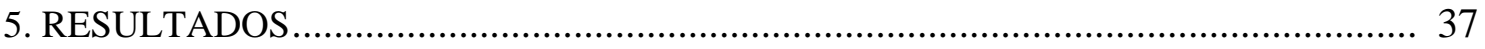

5.1 Análise da rotulagem dos produtos sem glúten à luz da legislação ................................. 37

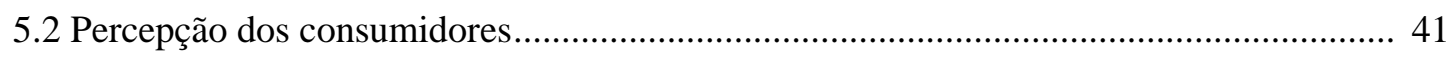

5.2.1 Caracterização da amostra de consumidores............................................................... 41

5.2.2 A percepção dos consumidores sobre os PSG industrializados - Análise das respostas objetivas

5.2.3 A percepção dos consumidores sobre os PSG industrializados - Análise do Sujeito do Discurso Coletivo

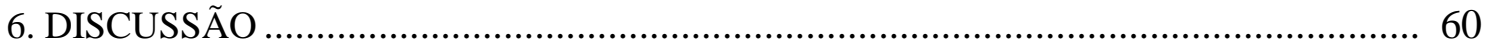

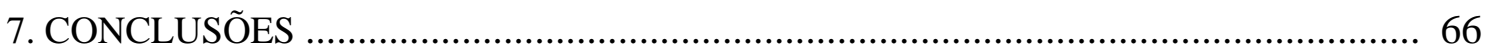

8. SUGESTÕES PARA TRABALHOS FUTUROS ....................................................... 67

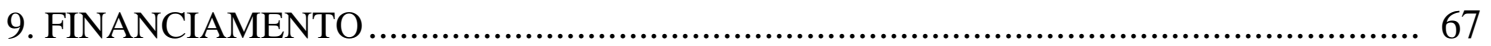

10. DECLARAÇÃO DE CONFLITO DE INTERESSES ................................................... 67

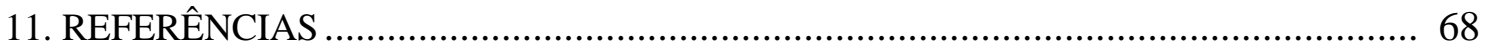

Anexo I - Parecer do Comitê de Ética em Pesquisa .......................................................... 76

Anexo II - Características socioeconômicas e demográficas gerais dos grupos Segue e Não segue

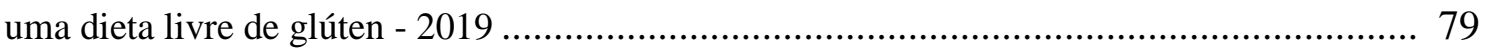

Apêndice I - Termo de Consentimento Livre e Esclarecido .............................................. 80

Apêndice II - Questionário Sobre a Percepção dos Consumidores em Relação ao Glúten ...... 83

Apêndice III. Folder virtual ................................................................................ 86

Apêndice IV - Informações para publicação do artigo ................................................... 91 


\section{LISTA DE QUADROS E FIGURAS}

Quadro 1. Legislação e aspectos normativos pertinentes ao escopo do estudo

Quadro 2. Tradução dos quesitos da LF. 10.674 para análise dos produtos sem glúten 34

Quadro 3. Parâmetros para análise da qualidade nutricional dos produtos sem glúten

Quadro 4. Parâmetros para análise no marketing nutricional dos produtos sem glúten 36

Figura 1. Símbolos geralmente presentes no painel frontal de rótulos de produtos sem glúten retirados do Google Imagens 


\section{LISTA DE TABELAS}

Tabela 1. Proporção de rótulos que cumprem a legislação - 2019

Tabela 2. Percentual de produtos sem glúten com quantidades elevadas de densidade energética , ácidos graxos saturados e trans e sódio - 2019

Tabela 3. Percentual de produtos sem glúten que possuem requisitos no rótulo que enaltecem a característica de não conter glúten - 2019

Tabela 4. Média de preço de produtos sem glúten por categoria comparados à suas versões tradicionais - Abril/2019

Tabela 5. Características socioeconômicas e demográficas dos grupos Segue e Não segue uma dieta livre de glúten - 2019

Tabela 6. Você segue ou tem/teve vontade de seguir uma dieta sem glúten? Se sim, por quê? - Grupo SEGUE

Tabela 7. Você segue ou tem/teve vontade de seguir uma dieta sem glúten? Se sim, por quê? - Grupo NÃO SEGUE

Tabela 8. Sob a perspectiva de saúde, qual a sua opinião sobre alimentos que contêm glúten? - Grupo SEGUE

Tabela 9. Sob a perspectiva de saúde, qual a sua opinião sobre alimentos que contêm glúten? - Grupo NÃO SEGUE

Tabela 10. $O$ que você pensa de um alimento cujo rótulo está escrito "não contém glúten"? - Grupo SEGUE

Tabela 11. O que você pensa de um alimento cujo rótulo está escrito "NÃO CONTÉM GLÚTEN"? - Grupo NÃO SEGUE

Tabela 12. Se você precisasse perder peso, você compraria alimentos com ou sem glúten? Por quê? - GRUPO SEGUE

Tabela 13. Se você precisasse perder peso, você compraria alimentos com ou sem glúten? Por quê? - Grupo NÃO SEGUE 


\section{LISTA DE GRÁFICOS}

Gráfico 1. Frequência de leitura do rótulo de alimentos, segundo os grupos Segue e Não Segue a DLG.

Gráfico 2. Intenção de aquisição de produto que Contém Glúten, segundo os grupos Segue e Não Segue a DLG

Gráfico 3. Intenção de aquisição de produto que Não Contém Glúten, segundo os grupos Segue e Não Segue a DLG

Gráfico 4. Consumo de alimentos com glúten segundo os grupos Segue e Não Segue a DLG

Gráfico 5. Meios de adquirir informações sobre glúten segundo os grupos Segue e Não Segue a DLG 


\section{LISTA DE ABREVIATURAS}

ACELBRA

ANVISA

AT

CAPES

DC

DLG

DM1

DSC

ELISA

FAO

FENACELBRA

GS

GNS

HLA

PSG

SGNC

SII

TCLE

WHO
Associação dos Celíacos do Brasil

Agência Nacional de Vigilância Sanitária

Alergia ao Trigo

Coordenação de Aperfeiçoamento de Pessoal de Nível Superior

Doença Celíaca

Dieta Livre de Glúten

Diabetes Mellitus Tipo 1

Discurso do Sujeito Coletivo

Enzyme-Linked Immunosorbent Assay

Food and Agriculture Organization

Federação Nacional das Associações dos Celíacos do Brasil

Grupo Segue

Grupo Não Segue

Human Leukocyte Antigen

Produtos Sem Glúten

Sensibilidade ao Glúten Não Celíaca

Síndrome do Intestino Irritável

Termo de Consentimento Livre e Esclarecido

World Health Organization 


\section{INTRODUÇÃO}

A demanda de produtos sem glúten (PSG) industrializados vem aumentando no mercado atual, por dois motivos principais. Em primeiro lugar, devido ao crescimento do número de indivíduos diagnosticados com doença celíaca ou outros tipos de desordens relacionadas ao glúten, cujo único tratamento conhecido é eliminação permanente dessa proteína da dieta (FOSCHIA et al., 2016). Em segundo lugar, o fator que também pressiona a demanda desses produtos, compondo o maior grupo de consumidores de PSG (REILLY, 2016), são as dietas da moda, que associam a exclusão do glúten da rotina alimentar à perda de peso e a benefícios à saúde, associação essa cientificamente questionável (PSZCZOLA, 2012).

Desde quando o homem passou a se fixar à terra, desenvolvendo a agricultura, o glúten, entre outras proteínas do trigo, faz parte da dieta humana. A facilidade no cultivo deste cereal e sua adaptação a diferentes condições climáticas o tornam um dos alimentos de mais fácil acesso (CRUCHET; LUCERO; CORNEJO, 2016).

O glúten é um complexo de proteínas de armazenamento inerente à composição de cereais como trigo, cevada, centeio, mas pode ser encontrado por contaminação cruzada na aveia, e em seus subprodutos. Essa proteína tem uma grande importância tecnológica para a produção de massas alimentícias, e na panificação de maneira geral, ao conferir viscoelasticidade à massa, determinando propriedades de aparência e textura ao produto final (GAESSER; ANGADI, 2015; AZIZ et al., 2015; ZANNINI et al., 2012)

Porém, existem indivíduos que têm uma predisposição genética denominada Doença Celíaca (DC), a qual gera complicações pela inflamação desencadeada por frações do glúten como a gliadina e a glutenina (FASANO; CATASSI, 2012). Existem outras desordens que levam a exclusão do glúten da dieta, todavia, a DC é a de maior prevalência mundial, além de causar danos graves (LUDVIGSSON et al., 2013).

Para segurança do consumidor com intolerância ao glúten, foram criadas duas normas. A Lei Federal n ${ }^{\circ}$ 8.543, de 23 de dezembro de 1992 a qual "determina a impressão de advertência em rótulos e embalagens de alimentos industrializados que contenham glúten, a fim de evitar a doença celíaca ou síndrome celíaca”, posteriormente substituída pela Lei Federal no 10.674 (BRASIL, 2003), que “obriga a que os produtos 
alimentícios comercializados informem sobre a presença de glúten, como medida preventiva e de controle da doença celíaca". No entanto, as palavras "evitar" ou "medida preventiva”, inerentes a essas leis, possuem valor emocional ${ }^{1}$ podendo ser interpretadas pelo consumidor como uma indicação de que o consumo de alimentos com glúten é prejudicial.

De fato, as empresas não se submetem a essa legislação passivamente, adaptam tal determinação, transformando-a em um elemento de sua estratégia de concorrência. Evidência disto foi encontrada por $\mathrm{Wu}$ et al. (2015), que observando a escolha de alimentos por consumidores em supermercados e restaurantes de diversos países, entre estes os Estados Unidos, perceberam que muitos preferiam a alternativa sem glúten, acreditando ser de melhor qualidade nutricional. A partir dessa observação, realizaram um estudo para mostrar as diferenças na composição nutricional entre as versões tradicional e sem glúten de alguns alimentos, analisando as informações nutricionais.

Wu et al. (2015) constataram que os produtos sem glúten possuíam quantidade de ácidos graxos saturados, sódio, carboidratos e valor energético semelhante, quando comparados aos alimentos na versão tradicional, e na maioria das vezes, menor quantidade de proteínas. Teethira et al. (2015), por sua vez, salientou a existência de maior quantidade de carboidratos e lipídeos em alimentos sem glúten. Essas características ocorrem devido aos ingredientes de baixa qualidade nutricional utilizados para compensar a ausência do glúten, como a farinha refinada de arroz, a fécula de mandioca, a fécula de batata e fontes de ácidos graxos.

O jornal americano The New York Times, em 2014, publicou a matéria “A big bet on gluten-free" que retratou o crescimento do mercado de PSG, mostrando o aumento da proporção desses produtos nas prateleiras dos supermercados, e o número de pessoas que os procuram sem ter qualquer tipo de intolerância. A reportagem ainda reforçou que grandes indústrias produzem versões sem glúten de diversos produtos, alegando maior qualidade por meio de anúncios e informações nas embalagens inclusive de produtos que, naturalmente, já não o contém, como pipoca, batatas fritas, nozes e biscoitos de arroz. Nessa mesma direção, em maio/2019, o jornal espanhol Murcia Economia em uma reportagem questionou se a alegação de ausência de glúten em certos produtos era uma

\footnotetext{
1 "Valor emocional é o valor econômico dos sentimentos" (Barlow, J. and Maul, D, 2000, p.2) https://books.google.com.br/books?id=ewZOLB0BpksC\&printsec=frontcover\&hl=pt-BR\#v=onepage\&q\&f=false Emotional Value: Creating Strong Bonds with Your Customers,
} 
informação para os que necessitam conhecer as características do produto ou de fato uma estratégia de marketing para venda destes produtos, sugerindo assim o uso indevido de uma informação importante para os consumidores intolerantes ao glúten!

No Brasil, a variedade de produtos que se caracterizam pela ausência de glúten é significativa, bem como o contingente de pacientes que sofrem com a intolerância a essa proteína. Considerando que a concorrência extra preço é inerente à indústria alimentícia, ao adotar as mais diversas estratégias de marketing nutricional para diferenciar seus produtos, inclusive a desinformação sobre as vantagens e desvantagens do componente glúten justifica-se investigar a obediência das empresas à legislação vigente sobre o rótulo destes produtos, e a percepção dos consumidores, a respeito de uma Dieta Livre de Glúten (DLG), visando oferecer subsídios para uma política de promoção da saúde que favoreça a escolha informada dos consumidores. 


\section{EMBASAMENTO TEÓRICO}

\subsection{Doença celíaca e outras desordens relacionadas ao glúten}

As desordens relacionadas ao glúten estão sendo cada vez mais identificadas em diversas partes do mundo, em especial na Europa, Estados Unidos e alguns países asiáticos, em decorrência do aperfeiçoamento nas técnicas diagnósticas. A prevalência é de aproximadamente 5\%, sendo a doença celíaca a mais predominante, com cerca de 1,4\% da população mundial, seguida da sensibilidade ao glúten e alergia ao trigo (CATASSI; GATTI; FASANO, 2014; ELLI et al., 2015; SINGH et al., 2018).

A Doença Celíaca (DC) é uma enteropatia autoimune permanente que se desenvolve em indivíduos geneticamente suscetíveis, em conjunto com fatores ambientais, afetando principalmente crianças, mulheres e descendentes de Europeus. Os genes HLA-DQ2 e HLA-DQ8, que foram encontrados em 95\% dos pacientes, são expressos desencadeando a resposta imunológica no intestino, o qual não reconhece as frações do glúten gerando uma inflamação que ocasiona atrofia das vilosidades, intestinais, comprometendo suas funções de secreção enzimática e absorção de nutrientes (FASANO; CATASSI, 2012; SINGH et al., 2018). Uma outra possível consequência dessa inflamação é a intolerância à lactose secundária, por conta da produção da enzima lactase ocorrer no ápice das vilosidades (OJETTI et al., 2005).

$\mathrm{Na}$ DC podem se desenvolver tanto sintomas gastrointestinais, como diarreia, vômito, constipação, dor e distensão abdominal; quanto sintomas extra intestinais, como fadiga, anemia por deficiência de ferro, osteopenia e osteoporose, dermatite herpetiforme, problemas neurológicos e psicológicos, puberdade tardia, infertilidade em mulheres, baixa estatura e perda de peso (GUANDALINI; ASSIRI, 2014).

Apesar de não estar relacionada com o desenvolvimento da DC, a Diabetes Mellitus Tipo 1 (DM1) parece se constituir em fator de risco para o aparecimento da DC (SEE et al., 2015), provavelmente porque a DM1 também é uma doença autoimune, e compartilha a mesma variante genética DQ2.

Na Sensibilidade ao Glúten Não Celíaca (SGNC), os sintomas gastrointestinais e alguns sintomas extra intestinais como fadiga, dor de cabeça e muscular, dermatite, depressão e anemia são relatados, porém sem a reação autoimune e inflamatória 
encontrada na DC (CATASSI et al., 2013). Normalmente, os indivíduos se autodiagnosticam com SGNC, e antes mesmo de buscarem orientação médica, descontinuam o consumo de alimentos que possuem glúten em sua composição (REILLY, 2016). Skodje et al. (2018), em um ensaio clínico, comprovaram que as queixas relacionadas a SGNC, na verdade, estão ligadas aos frutanos, definidos como polissacarídeos da frutose, presentes em diversos alimentos, com e sem glúten, como trigo, alho, banana e raízes tuberosas (yacon). Por não serem digeridos pelas enzimas humanas, de um lado, os frutanos são fermentados pela microflora intestinal, de modo benéfico, aumentando o bolo fecal e sendo substrato prebiótico, mas, por outro, também, podem ocasionar desconfortos gastrointestinais em alguns indivíduos.

A adesão a uma DLG por toda a vida é a única forma de tratamento para tais enfermidades, especialmente a DC, que depende inteiramente de uma alimentação isenta de glúten para regredir o quadro inflamatório e reduzir seus efeitos negativos no organismo (CATASSI; FASANO, 2008; WATKINS; ZAWAHIR, 2017). Infelizmente, a informação a respeito de todos os alimentos que contém glúten ainda não é padronizada nem suficientemente difundida. Os consumidores, em geral, buscam sobre o assunto por meio da mídia ou das redes sociais com informações cuja qualidade científica não está assegurada. Uma exceção são as associações para celíacos que possuem e oferecem conhecimento adequado. (SILVESTER et al., 2016).

A ausência de tratamento na DC pode ocasionar uma série de consequências negativas ao organismo. A taxa de morbidade e mortalidade pela DC é alta, destacandose complicações como deficiências nutricionais e câncer, sendo o mais comum, o linfoma intestinal (SILVA; FURLANETTO, 2010). A detecção tardia da DC aumenta ainda mais o risco a essas complicações, e a incidência de linfoma não Hodgkin. Outro problema é a osteoporose em níveis elevados entre idosos celíacos sem tratamento, que comparados a jovens e adultos celíacos, apresentam mais dificuldade na recuperação histológica das vilosidades e maior comprometimento ósseo (SEE et al., 2015).

Por outro lado, muitos indivíduos saudáveis ou com outras comorbidades optam pela retirada desse componente da dieta por acreditarem em benefícios decorrentes da restrição ao glúten, mesmo sem comprovação, o que pode ser prejudicial à saúde dos mesmos, pela baixa qualidade nutricional inerente a este tipo de dieta (BROUNS; VAN BUUL; SHEWRY, 2013). 


\subsection{Especificidades sobre a presença de glúten nos alimentos}

O glúten é composto por duas frações proteicas classificadas de acordo com o comportamento em solução de etanol: as gliadinas, que são solúveis, e as gluteninas, que são insolúveis (WIESER, 2007). Ambas as frações possuem grande importância tecnológica na panificação: as gliadinas são responsáveis por atribuir viscosidade e extensibilidade às massas, e as gluteninas por conferir firmeza e elasticidade (LAMACCHIA et al., 2014).

Elas também são responsáveis pela ação tóxica no organismo, em casos de intolerância ao glúten (WIESER, 2008), sendo totalmente restrito o consumo de trigo, cevada e centeio, pois $80 \%$ da parte proteica destes cereais correspondem ao glúten. Além desses cereais também há restrição ao consumo de aveia, em decorrência da contaminação cruzada $^{2}$, pois a aveia originalmente não possui glúten, (LAMACCHIA et al., 2014; ROSELL et al., 2014).

Apesar de o ideal ser a isenção total do glúten da dieta de um celíaco, as técnicas na produção destes alimentos ainda são limitadas (SEE et al., 2015), sendo assim, o Codex Alimentarius da Food and Agriculture Organization e World Health Organization FAO/WHO (2008) estabeleceram que alimentos naturalmente livres de glúten podem conter até $20 \mathrm{mg}$ de glúten em cada $100 \mathrm{~g}$ de alimento; já para os alimentos sem glúten industrializados, o valor detectado não deve ser superior a $10 \mathrm{mg} / 100 \mathrm{~g}$ de alimento. A presença de glúten pode ser quantificada por meio de diversas técnicas laboratoriais, como a de ELISA (enzyme-linked immunosorbent assay), a mais conhecida e utilizada.

Há um intenso controle de qualidade dos PSG com base no descrito no Codex Alimentarius (2008), que exige uma certificação que é mais encontrada em produtos com marcas conhecidas, e consequentemente mais caros, pois quanto maior o controle, maiores são os custos. Segundo Rostami et al. (2017), alguns estudos identificaram que há contaminação com glúten em maior proporção em PSG mais baratos, expondo a população de baixa renda, que só tem essa opção, a um risco maior.

\footnotetext{
${ }^{2}$ De acordo com a RDC n²6/2015, a contaminação cruzada de alimentos consiste na presença de alérgenos alimentares não adicionados intencionalmente, mas em decorrência do processo de produção, como no cultivo, manipulação, preparação, armazenamento, embalagem e transporte, ou por contaminação ambiental.
} 


\subsection{Qualidade nutricional dos produtos sem glúten}

Tortora et al. (2005) constataram aumento da obesidade, da resistência à insulina e de síndrome metabólica entre pacientes que consumiam PSG, fato esperado pois são produtos que geralmente possuem elevada quantidade de ácidos graxos saturados, açúcares e sódio.

Indivíduos que optam pela ingestão de alimentos sem glúten, assim como, os celíacos, têm o consumo de energia obtida de lipídeos, e menos de carboidratos (MARTIN et al, 2013). Em 2010, um estudo com crianças suíças celíacas relatou o aumento de $14 \%$ do consumo de ácidos graxos saturados, e menos de $4 \%$ de consumo de ácidos graxos poli-insaturados, (OHLUND et al., 2010).

De acordo com a American Diabetes Association, o percentual de lipídeos de uma dieta normolipídica deve ser de 30\%, distribuídos em 10\% ácidos graxos saturados, $10 \%$ de ácidos graxos monoinsaturados e 10\% de ácidos graxos poli-insaturados (AGUIAR et al. 2009).

Theethira et al. (2014) mostraram, em um estudo de revisão, o aumento do consumo de alimentos, com maior densidade energética, lipídeos e menor proporção de micronutrientes, em especial cálcio, ferro, tiamina, riboflavina, niacina e ácido fólico, associado às Dietas Livres de Glúten (DLG). Nessa mesma direção, Rybicka (2018) reafirma que o perfil nutricional da DLG é deficiente nestes micronutrientes, assim como no magnésio e zinco, além de conter alta quantidade de lipídeos e ácidos graxos trans. $\mathrm{O}$ desequilíbrio da DLG pode ocasionar problemas de saúde. A deficiência de ácido fólico, por exemplo, pode causar a elevação de homocisteína sérica, aumentando o risco de doenças cardiovasculares (THEETHIRA et al., 2014).

Wu et al. (2015) e Missbach et al. (2015) realizaram análises na Austrália e na Áustria, respectivamente, com uma vasta quantidade de PSG e verificaram que são semelhantes às suas versões tradicionais, não oferecendo nenhum benefício adicional à saúde. Pelo contrário, indicando o seu consumo pelos pacientes intolerantes como um fator para ganho de peso, pois em alguns estudos pacientes celíacos registraram aumento de peso após o início da DLG (THEETHIRA et al., 2015). Mulheres celíacas britânicas, comparadas às não celíacas da região, obtém mais energia pelo alto consumo de bolachas doces (WILD et al., 2010). Kabbani et al. (2012) constataram que no momento do 
diagnóstico da DC, o IMC dos pacientes era menor comparado a população local, e após 3 anos seguindo uma DLG, 20,5\% desenvolveram sobrepeso e 11,5\% obesidade.

Em relação a crianças celíacas, houve aumento da prevalência de sobrepeso de $8,8 \%$ para $11,4 \%$, e de obesidade de $5,3 \%$ a $8 \%$, em crianças italianas que aderiram a DLG (NORSA et al., 2013), o que foi observado pelo estudo de Wiech et al. (2018) sobre o aumento considerável do IMC de crianças celíacas polonesas. 


\subsection{Marketing nutricional e os produtos sem glúten}

A economia de mercado tem como referência o modelo de concorrência perfeita ou pura, no qual as empresas estabelecem apenas a quantidade que desejam produzir ao preço vigente no mercado, obtendo o lucro normal. Contudo a realidade não se comporta de acordo com esse modelo ideal, que supõe a homogeneidade do produto, entre outros pressupostos. As empresas buscam se destacar no mercado, diferenciando seus produtos visando alcançar lucros extraordinários (SCHERER, 1970; VARIAN, 2000).

Quanto mais concentrada a estrutura de um mercado, ou seja, quanto maior a participação de algumas empresas, maior a probabilidade de uma conduta ativa ser observada. Em determinados mercados concentrados as empresas buscam realizar investimentos recorrentes para o desenvolvimento de novos atributos para seus produtos, gastos em propaganda e marketing tornando seus produtos diferentes e únicos para nichos de mercado específicos. Em outras palavras, as empresas competem por maiores fatias do mercado mediante estratégias de concorrência preço e extra preço, obtendo com esse comportamento um desempenho favorável caracterizado por lucros, crescimento e avanços tecnológicos (SCHERER; ROSS, 1990).

Especificamente, as empresas do ramo de produtos alimentícios utilizam diversas estratégias para maximizar o lucro e vencer a concorrência, como: seleção dos melhores locais para distribuição; oferta de serviços ao cliente (ex.: Serviço de Atendimento ao Consumidor); aprimoramento de propriedades físicas do produto (ex.: sabor, aroma, combinação de ingredientes e melhorias da composição nutricional); propriedades visuais do produto (ex.: desde formato da embalagem e porções, informações contidas na rotulagem e alegações nutricionais) (SCHERER; ROSS, 1990; GONSALVES, 1997; MACHADO, 2003; MACIEL, 2012). A disfuncionalidade do glúten para determinados consumidores, assim como a possibilidade de associá-lo a prejuízos à saúde abre campo para a diferenciação de produtos e consequentemente alegações passíveis de exploração pelo marketing.

De acordo com Kotler (2000) o marketing é um conjunto de técnicas que analisa as oportunidades de mercado e desenvolve estratégias para comercialização do produto baseando-se nos desejos, necessidades e demandas do público-alvo. 
Rodrigues (2010) diferencia o marketing alimentar do marketing nutricional, sendo que o alimentar está envolvido com toda a cadeia de produção do alimento e é voltado a criar vínculo entre o produtor e o consumidor; e o nutricional está direcionado a diferenciação dos produtos, diferenciação esta informada ao consumidor por meio da propaganda, rotulagem nutricional, e de alegações. Stringheta et al. (2007) reforçam que o marketing nutricional influencia a escolha dos alimentos e consequentemente os hábitos alimentares dos consumidores.

Kotler e Keller (2006) definem que a embalagem engloba as atividades de projeto e produção do recipiente ou envoltório de um produto. Embalagens elaboradas podem criar valor de conveniência e promocional, e são o primeiro contato do comprador com o produto, podendo atraí-lo ou afastá-lo. No que tange a produtos alimentícios, na rotulagem está expressa parte da estratégia comercial do produto, veiculando os principais apelos nutricionais e de saúde, e ressaltando suas propriedades e qualidade (COBRA, 2009), logo, a rotulagem possui papel fundamental para a construção e fortalecimento da marca (KOTLER; KELLER, 2006; GONSALVES, 1997).

No presente trabalho, o marketing nutricional é definido como o uso de informações de cunho nutricional para diferenciar o produto e assim incrementar as vendas. Todavia, em função da assimetria de informação (o consumidor não tem base para interpretar adequadamente a informação nutricional) essa estratégia de concorrência pode induzir consumidores a comprar o produto ao considerá-lo algo que de fato ele não é. Uma ilustração desse argumento seria a aquisição de um PSG por interpretá-lo como saudável, quando de fato é um produto com elevado teor de sódio e densidade energética, como os produtos similares tradicionais, adequado tão somente para pessoas celíacas que dependem de uma DLG (WU et al., 2015).

As alegações nutricionais presentes nos rótulos dos alimentos influenciam diretamente no comportamento dos consumidores, afetando áreas cerebrais e consequentemente processos motivacionais para a escolha e compra de um produto. Informações sobre benefícios nutricionais, certificação de "produtos orgânicos", preço do produto geram valor emocional e influenciam na escolha e nas medidas de avaliação como o gostar e o quanto estão dispostos a pagar ("willingness to pay") (SINGH et al., 2018). 
Para os consumidores intolerantes ao glúten, a informação sobre a composição dos alimentos e principalmente o conhecimento acerca da presença ou ausência de glúten é fundamental para a preservação da saúde. Eles gastam cerca de 10 a $20 \mathrm{~h}$ por mês analisando rótulos para certificar-se de que aquele alimento não lhes fará mal. Para as empresas, por outro lado, tal aspecto representa uma oportunidade que pode ser explorada como elemento de seu marketing nutricional, compelindo outros consumidores à compra sem que tenham necessidade de produtos com tais características específicas (BOGUE; SORENSON, 2008; SEE et al., 2015) e dessa forma induzindo a uma dieta, nutricionalmente pobre (BROUNS; VAN BUUL; SHEWRY, 2013).

Algumas evidências mostram os problemas decorrentes do uso do tema glúten nas estratégias de marketing da indústria. Entre 2009 e 2014, triplicou o número de indivíduos nos Estados Unidos que evitam alimentos sem glúten alegando sentirem benefícios com a restrição. Esse tipo de escolha foi encontrado majoritariamente em grupos de alta renda, brancos, mulheres e indivíduos com doenças na tireoide pelo receio da associação entre doença autoimune da tireoide e doença celíaca (BLACKETT et al., 2018).

Moore (2014) entrevistou pessoas que aderiram a uma DLG sem diagnóstico de doença celíaca e que sentiram melhoras nos seus diversos tipos de problemas, como dores no estômago, fadiga e descontrole alimentar. Nesse estudo, alguns relatos evidenciaram a falta de informação ou conhecimento equivocado acerca dos benefícios da ausência de glúten na dieta.

O trabalho de Silvester et al. (2016) reporta que 34\% dos participantes que não tinham doença celíaca e seguiam a DLG justificaram o uso de tais dietas por considerarem os PSGs mais saudáveis, serem o melhor tratamento para a Síndrome do Intestino Irritável (SII) ou para autismo, e ainda serem auxiliares na perda de peso. No entanto, de acordo com as respostas obtidas neste estudo, em questionário validado que foi aplicado para analisar o nível de conhecimento sobre este tipo de dieta, esses indivíduos foram os que menos pontuaram acerca do assunto, além de ser o grupo que menos procurava ajuda profissional para acompanhar a restrição e seus efeitos, mas em contrapartida eram os que menos sofriam com distúrbios psicológicos, depressão ou raiva, em decorrência da restrição, quando comparados com pessoas que possuíam a DC.

As pessoas que seguem uma DLG sem indicação médica acreditam na associação do glúten a diversas desordens de saúde sem embasamento médico/científico; desconfiam 
da autoridade médica; e diagnosticam outras pessoas, incentivando a adesão à restrição (MOORE, 2014).

O mercado de produtos com alegações relacionadas a saúde e bem-estar, ou seja, funcionais, vem crescendo de 15 a $20 \%$ anualmente, comparado ao crescimento de 2 a 4\% para o mercado de produtos tradicionais. No caso dos PSGs, de um lado, o aumento do preço comparado a versão tradicional pode chegar a 500\%, em função das dificuldades tecnológicas da produção e da lista de ingredientes para substituição do glúten, bem como pela pressão de demanda estimulada pela propaganda não exatamente esclarecedora inerente às estratégias de concorrência nesses mercados. Por outro lado, o alto custo destes produtos dificulta a adesão à DLG de indivíduos que deles necessitam (ISHIMOTO, 2001, BOGUE; SORENSON, 2008; PANAGIOTOU; KONTOGIANNI, 2017).

De acordo com See et al. (2015), com o aumento do número de PSGs, estima-se redução no preço deles, auxiliando àqueles que necessitam. No entanto, indivíduos que aderem a DLG por escolha própria, não são excessivamente sensíveis ao preço e estão dispostos a pagar o custo extra agregado nestes produtos, pondo em dúvida se a tendência de queda do preço dos PSGs irá se concretizar (TOPPER, 2014).

Ante tais considerações, o presente estudo analisou o impacto das informações nutricionais e alegações contidas na rotulagem de produtos industrializados que não contém glúten, diferente de suas versões tradicionais, sobre as escolhas de consumidores. 


\section{OBJETIVOS}

Objetivo Geral: Analisar a influência do marketing nutricional dos produtos sem glúten industrializados sobre as escolhas de consumidores leigos que não têm doença celíaca, e seguem ou não seguem uma dieta livre de glúten.

\section{Objetivos Específicos:}

- Identificar a existência de marketing nutricional e a qualidade nutricional dos produtos sem glúten industrializados (pães, bolos, bolachas e massas alimentícias), vendidos em lojas virtuais, com base em normatizações;

- Investigar a interpretação da amostra selecionada acerca das alegações relativas ao glúten contidas no rótulo dos produtos sem glúten industrializados, bem como a decisão de compra dada a alegação;

○ Propor aprimoramentos à legislação vigente e à divulgação da informação sobre o glúten junto a órgãos públicos correlatos. 


\section{MATERIAIS E MÉTODOS}

O presente estudo envolveu duas etapas. A primeira etapa, destinada a identificar a existência de marketing nutricional na rotulagem de produtos sem glúten (PSGs), envolveu o levantamento do universo de PSGs industrializados, cujas versões tradicionais são derivadas de trigo (pães, bolos, bolachas e massas alimentícias), em três lojas virtuais que vendem apenas alimentos sem glúten. Essa escolha baseou-se no fato de que a variedade de produtos em tais lojas é abrangente e todas as informações necessárias para a realização da aquisição estão disponíveis, conforme o Artigo 6 do Código de Defesa do Consumidor (BRASIL, 1990). Todas as informações obtidas foram extraídas dos rótulos dos produtos vistos com ampliador de imagem, e também nas informações da página do produto no site.

Os produtos das categorias selecionadas são industrializados e têm suas versões tradicionais com glúten (pão, bolo, bolacha e massas alimentícias). Foram excluídos os alimentos que não tinham todos os tópicos propostos para análise descritos na página virtual (ex.: informação nutricional); não foram incluídas misturas para preparação, só foram analisados produtos prontos. As visitas nas lojas virtuais foram realizadas em março/2019, e a consulta dos preços em abril/19; o preço das versões tradicionais foram coletados na Loja Online do Supermercado Pão de Açúcar, no mesmo mês de abril/19, os preços foram calculados na unidade estabelecida pelo produto tradicional, pois os PSGs geralmente são vendidos em quantidades menores em decorrência da sua menor vida de prateleira.

A análise dos rótulos foi realizada com base no modelo desenvolvido por Cyrillo (2001), o qual consiste na tradução da legislação pertinente em quesitos que permitem questionar os termos da rotulagem. Foi adaptado o formulário desenvolvido por Maciel (2012) para o registro dos dados dos rótulos de acordo com os quesitos avaliados. por meio dos quesitos estabelecidos no Quadro 1. O primeiro quesito se refere ao cumprimento da LF 10.674/2004 a qual torna obrigatório a necessidade da alegação “contém glúten" ou "não contém glúten" nos rótulos de produtos industrializados (Quadro 1). Para avaliar se o produto atendia a preceitos de qualidade nutricional, e se a informação constante da alegação não levaria a uma interpretação equivocada da 
qualidade do produto, foi utilizada de modo complementar a RDC $24 / 2010^{3}$, que, embora não esteja em vigor, contém parâmetros nutricionais básicos para definir se um produto pode ou não ser considerado saudável. O parâmetro de densidade energética foi obtido no estudo de Rolls (1999), à semelhança do procedimento adotado por Maciel (2012).

O Quadro 2 apresenta a tradução da LF 10.674/2003 para análise do cumprimento da legislação vigente, e os Quadros 3 e 4 apresentam a tradução de parâmetros em quesitos que permitiram identificar se o produto possui elevada densidade energética, excesso de quantidade de ácidos graxos saturados e trans e de sódio, com base nos dados apresentados na rotulagem por $100 \mathrm{~g}$ de porção, além da presença ou não de marketing nutricional por meio de alguma informação especial destacada nos rótulos dos PSGs.

Considerou-se "informação especial” qualquer alegação escrita ou em formato de símbolo, destacada presente no painel frontal do rótulo para enfatizar a característica de não conter glúten. Como indicado na RDC 259/2002, "Deve constar no painel principal, a denominação de venda do alimento, sua qualidade, pureza ou mistura, quando regulamentada, a quantidade nominal do conteúdo do produto, em sua forma mais relevante em conjunto com o desenho, se houver, e em contraste de cores que assegure sua correta visibilidade” (BRASIL, 2002), consistindo a parte da embalagem que mais atrai a atenção do consumidor. Logo, qualquer expressão alocada no painel principal do produto, além do que é obrigatório, é uma forma de diferenciá-lo, tornandose uma estratégia de marketing.

A análise foi feita por meio de frequências absolutas e relativas nos mesmos moldes do realizado por Cyrillo (2001).

Na segunda etapa do estudo foi realizada uma pesquisa primária, qualitativa, junto a uma amostra de consumidores não celíacos, estratificados conforme declaração do participante, na resposta da Pergunta 1 (Você segue ou tem/teve vontade de seguir uma

${ }^{3}$ A RDC 24/2010 foi publicada em 24 de junho de 2010, pela ANVISA (Agência Nacional de Vigilância Sanitária), e trata sobre a forma de publicidade para divulgação e promoção comercial de alimentos e bebidas com quantidades elevadas de açúcar, ácidos graxos saturados, ácidos graxos trans e sódio. A manifestação contrária da ABIA (Associação Brasileira da Indústria de Alimentos) perante a Justiça para vigência desta Resolução culminou na proibição de sua aplicação por meio de uma liminar judicial, posteriormente julgada, em 2013, pela 6. ${ }^{a}$ Turma do Tribunal Regional Federal da 1. ${ }^{a}$ Região a qual negou os recursos propostos pela ANVISA, e proibiu a vigência da legislação relatando que "a ANVISA não tem competência para regulamentar propaganda e publicidade comercial" (Conselho da Justiça Federal, 2015). Apesar de sua proibição, os indicadores por ela adotados são relevantes para determinar a qualidade nutricional de produtos alimentícios. 
dieta sem glúten? Se sim, por quê?) do questionário, em relação a seguir (GS - Grupo Segue) ou não seguir (GNS - Grupo Não Segue) uma dieta livre de glúten (DLG). Pessoas que se autodiagnosticaram com DC foram incluídas no estudo, pois autodiagnóstico não é considerado como uma condição clinicamente confiável. Os critérios de exclusão aplicados foram: pessoas que relataram profissão de médico ou nutricionista, ou que possuem DC, uma vez que o objetivo da pesquisa é analisar a influência do marketing nutricional relacionado ao glúten sobre as escolhas de consumidores leigos sem DC.

Para realização da pesquisa junto aos participantes foi solicitada a leitura do Termo de Consentimento Livre e Esclarecido (Apêndice 1) antes do preenchimento do questionário. O presente projeto foi aprovado pelo comitê de ética em pesquisa da FCF/USP com o parecer $N^{\circ} 2.542 .919 / 2018$. A pesquisa consistiu na aplicação de questionários pela internet, com questões não invasivas, impondo risco mínimo para os respondentes.

Os consumidores foram convidados a participar da pesquisa pessoalmente em um supermercado, dois hortifrútis e uma loja de produtos naturais da cidade de São Paulo, e por meio virtual, em grupos de redes sociais de celíacos como a FENALCEBRA (Federação Nacional das Associações dos Celíacos do Brasil); a ACELBRA (Associação dos Celíacos do Brasil) de São Paulo, Santa Catarina e Rio de Janeiro; o Rio Sem Glúten; o Doença Celíaca - Brasil e o Celíacos do Brasil. Apesar destas associações referenciarem os celíacos, grande parte do público que busca seguir uma DLG também é seguidora desses sítios para obter informações sobre os alimentos sem glúten.

A permissão de divulgação da pesquisa dentro dos estabelecimentos foi dada pelos seus gerentes. Não foram realizadas entrevistas; em ambos os casos, os indivíduos responderam o mesmo questionário virtual, os participantes abordados pessoalmente apenas disponibilizaram seus endereços eletrônicos para o envio do link do questionário.

Eles responderam um questionário eletrônico, levando em média de 15 minutos para o preenchimento, via Formulários Google (Apêndice I) contendo perguntas discursivas e objetivas sobre o conhecimento relativo ao glúten (qualidades nutricionais, malefícios), produtos à base de cereais na versão sem glúten (pães, bolos, bolachas, massas alimentícias), sobre a interpretação derivada das alegações usadas pela indústria (identificadas na primeira etapa do estudo) além de questões socioeconômicas e demográficas (sexo, idade, escolaridade e nível socioeconômico). Antes da aplicação 
oficial dos questionários, foi realizado um teste piloto com 6 indivíduos para averiguar adequação e compreensão das questões, o que levou a reformulações marginais do questionário original.

Em contrapartida à participação da pesquisa, ao finalizar o questionário, que exigiu uma obrigatoriedade de resposta até a conclusão, os participantes tiveram direito a um folder virtual (Apêndice III) contendo explicações sobre o glúten, e a importância dos PSGs para um público-alvo específico como pessoas com DC.

O método de análise das questões discursivas foi o Discurso do Sujeito Coletivo (DSC) (LEFEVRE, 2000), técnica que agrega e sintetiza os relatos individuais em respostas combinadas gerando um relato coletivo do tema implícito a cada questão.

Pesquisas qualitativas na área da saúde, bem como em outras áreas, têm utilizado a técnica do DSC em decorrência de sua eficácia para o processamento e expressão das opiniões coletivas (LEFEVRE; LEFEVRE, 2006). O DSC resgata as representações sociais que são uma forma de conhecimento cujo objetivo é contribuir para a obtenção de uma opinião comum a um conjunto social (JODELET, 2001; LEFEVRE; LEFEVRE, 2014). A abordagem qualitativa realizada pelo método do DSC representa um recurso que extrai de discursos individuais ideias comuns a grupos sociais evidenciando as representações sociais sobre um tema, como no presente estudo que visa obter a percepção dos consumidores acerca dos PSGs industrializados.

Esse questionário foi respondido por um total de 148 participantes, no entanto, ao serem aplicados os critérios de exclusão, restaram apenas 54 consumidores para análise, dentre os quais, 32 indivíduos que seguem uma DLG, alocados no grupo GS (Grupo Segue) e 22 indivíduos que não seguem a DLG, GNS (Grupo Não Segue). Essa amostra tem um tamanho considerado adequado para análise pelo método do DSC (FURQUIM, 2012; GULINI et al., 2017; VINCHA et al., 2017). A adesão dos indivíduos recrutados pessoalmente foi muito menor comparada aos indivíduos recrutados virtualmente, dos 85 candidatos, os quais disponibilizaram seus endereços eletrônicos, apenas 23 responderam a pesquisa.

Para redigir o discurso para cada pergunta avaliando tanto as respostas do GS quanto do GNS, foram elaboradas Ideias Centrais (IC); cada IC aglomera as respostas com opiniões semelhantes para compor o discurso em primeira pessoa. As respostas sem sentido, ou que não expressavam alguma opinião, sendo apenas binária, "sim” ou "não", 
foram desconsideradas para a construção do DSC, bem como as ICs que refletiam a opinião de uma única pessoa. As respostas objetivas foram analisadas por meio de gráficos comparativos, e as informações socioeconômicas e demográficas foram analisadas por pelo Teste t de student e Teste Z para, respectivamente, avaliar igualdade de médias e proporções. 
Quadro 1. Legislação e aspectos normativos pertinentes ao escopo do estudo

\begin{tabular}{|c|c|c|c|c|c|c|}
\hline ORIGEM & TEOR & TIPO & DATA & PUBLICAC̣Á & DATA & PG \\
\hline $\begin{array}{l}\text { COORDENAÇÄO DE ESTUDOS } \\
\text { LEGISLAATIVOS (CEDI) }\end{array}$ & $\begin{array}{l}\text { Obriga a que os produtos alimenticios } \\
\text { comercializados informem sobre a presença de glúten, } \\
\text { como medida preventiva e de controle da doença } \\
\text { celiaca. }\end{array}$ & Lei 10.674 & 16 mai. 2003 & Diário Oficial da União & 19 mai. 2003 & 1 \\
\hline $\begin{array}{l}\text { AGËNCIA NACIONAL DE VIGILÄNCIA } \\
\text { SANITÁRIA }\end{array}$ & $\begin{array}{l}\text { Trata sobre a oferta, propaganda, publicidade, } \\
\text { informação e outras práticas correlatas cujo objetivo } \\
\text { seja a divulgação e a promoção comercial de } \\
\text { alimentos considerados com quantidades elevadas de } \\
\text { açúcar, de gordura saturada, de gordura trasss, de } \\
\text { sódio, e de bebidas com baixo teor nutricional. }\end{array}$ & $\begin{array}{l}\text { Resolução RDC n }{ }^{\circ} \\
24\end{array}$ & 15.jun. 2010 & Diário Oficial da União & 29.jun. 2010 & 46 \\
\hline
\end{tabular}

Quadro 2. Tradução dos quesitos da LF. 10.674 para análise dos produtos sem glúten

\begin{tabular}{|c|c|c|c|c|c|c|}
\hline ORDEM & $\begin{array}{l}\text { ENTIDADE } \\
\text { PUBLICAÇÃO }\end{array}$ & $\begin{array}{c}\text { LEI } \\
\text { RESOLUÇÃO PORTARIA }\end{array}$ & $\begin{array}{c}\text { ARTIGO } \\
\text { PARÁGRAFO DIRETRIZ }\end{array}$ & DEFINIÇÕES & CUMPR. & DESCUMPR. \\
\hline & CEDI & LEI 10.674 & Art. $1^{\circ}$ & $\begin{array}{l}\text { Art. } 1^{\circ} \text { - Todos os alimentos industrializados deverão conter em seu } \\
\text { rótulo e bula, obrigatoriamente, as inscrições "contém Glúten" ou "não } \\
\text { contém Glúten", conforme o caso. }\end{array}$ & & \\
\hline \multirow[t]{2}{*}{1} & & & & O alimento possui descrito em sua embalagem "não contém glúten"? & $\operatorname{Sim}$ & Não \\
\hline & CEDI & LEI 10.674 & Art. $1^{\circ} / \S 1$ & $\begin{array}{l}\S 1 \text { - A advertência deve ser impressa nos rótulos e embalagens dos } \\
\text { produtos respectivos assim como em cartazes e materiais de divulgação } \\
\text { em caracteres com destaque, nítidos e de fácil leitura. }\end{array}$ & & \\
\hline 2 & & & & $\begin{array}{l}\text { Os rótulos e embalagens dos produtos contém a advertência quanto à } \\
\text { presença do glúten, com caracteres em destaque, nítidos e de fácil leitura? }\end{array}$ & $\operatorname{Sim}$ & Não \\
\hline
\end{tabular}


Quadro 3. Parâmetros para análise da qualidade nutricional dos produtos sem glúten.

\begin{tabular}{|c|c|c|c|c|c|c|}
\hline ORDEM & $\begin{array}{c}\text { ENTIDADE } \\
\text { PUBLICAC̣ÄO }\end{array}$ & $\begin{array}{c}\text { LEI } \\
\text { RESOLUÇĀO PORTARIA }\end{array}$ & $\begin{array}{l}\text { ARTIGO } \\
\text { PARAGRAFO } \\
\text { DIRETRIZ }\end{array}$ & DEFINIÇÖES & \multicolumn{2}{|c|}{ RESPOSTA } \\
\hline & & $\begin{array}{l}\text { ROLLS B. et al Energy density but } \\
\text { not fat content of foods affected } \\
\text { energy intake Am J Clin Nutr } \\
1999 ; 69: 863-71\end{array}$ & & $\begin{array}{l}\text { ALIMENTO COM ELEVADA DENSIDADE } \\
\text { CALORICA é aquele que possui em sua } \\
\text { composição uma quantidade superior a } 1,5 \mathrm{kcal} \\
\text { por grama. }\end{array}$ & & \\
\hline \multirow[t]{2}{*}{1} & & & & Possui densidade calórica considerada elevada? & SIM & $\mathrm{NÄO}$ \\
\hline & ANVISA & $\mathrm{RDC} 24$ & Art. $4^{\circ} / \mathrm{V}$ & $\begin{array}{l}\text { V - ALIMENTO COM QUANTIDADE } \\
\text { ELEVADA DE GORDURA SATURADA é } \\
\text { aquele que posgui em sua composiç̃o uma } \\
\text { quantidade igual ou superior a } 5 \mathrm{~g} \text { de gordura } \\
\text { saturada por } 100 \mathrm{~g} \text { ou } 2,5 \mathrm{~g} \text { por } 100 \mathrm{ml} \text { na forma } \\
\text { como está a venda. }\end{array}$ & & \\
\hline \multirow[t]{2}{*}{2} & & & & $\begin{array}{l}\text { Possui quantidade de gordura saturada } \\
\text { considerada elevada? }\end{array}$ & SIM & $\mathrm{NÄO}$ \\
\hline & ANVISA & $\mathrm{RDC} 24$ & Art. $4^{\circ} / \mathrm{VI}$ & $\begin{array}{l}\text { VI - ALIMENTO COM QUANTIDADE } \\
\text { ELEVADA DE GORDURA TRANS é aquele } \\
\text { que possui em sua composição uma quantidade } \\
\text { igual ou superior a } 0,6 \mathrm{~g} \text { para } 100 \mathrm{~g} \text { ou } 100 \mathrm{ml} \text { na } \\
\text { forma como está exposto à venda. }\end{array}$ & & \\
\hline \multirow[t]{2}{*}{3} & & & & $\begin{array}{l}\text { Possui quantidade de gordura trans considerada } \\
\text { elevada? }\end{array}$ & SIM & $\mathrm{NÄO}$ \\
\hline & ANVISA & $\mathrm{RDC} 24$ & Art. $4^{\circ} /$ VII & $\begin{array}{l}\text { VII - ALIMENTO COM QUANTIDADE } \\
\text { ELEVADA DE SODIO é aquele que possui em } \\
\text { sua composição uma quantidade igual ou } \\
\text { superior a } 400 \mathrm{mg} \text { de sódio por } 100 \mathrm{~g} \text { ou } 100 \mathrm{ml} \\
\text { na forma como está exposto à venda. }\end{array}$ & & \\
\hline 4 & & & & Possui quantidade de sódio considerada elevada? & SIM & $\mathrm{NÄO}$ \\
\hline
\end{tabular}

Fonte: Adaptado de Maciel (2012). 
Quadro 4. Parâmetros para análise no marketing nutricional dos produtos sem glúten

\begin{tabular}{|c|c|c|c|c|c|c|}
\hline ORDEM & $\begin{array}{c}\text { ENTIDADE } \\
\text { PUBLICAÇÃO }\end{array}$ & $\begin{array}{c}\text { LEI } \\
\text { RESOLUÇÃo } \\
\text { PORTARIA }\end{array}$ & $\begin{array}{c}\text { ARTIGO } \\
\text { PARÁGRAFO } \\
\text { DIRETRIZ }\end{array}$ & DEFINIÇÕES & \multicolumn{2}{|c|}{ RESPOSTA } \\
\hline & ANVISA & $\mathrm{RDC} 24$ & Art. $4^{\circ} / \mathrm{IX}$ & $\begin{array}{l}\text { IX - APRESENTAÇÃO ESPECIAL é } \\
\text { qualquer forma de apresentação do } \\
\text { alimento que objetive induzir a } \\
\text { aquisição ou venda, tais como, } \\
\text { embalagens promocionais, embalagens } \\
\text { de fantasia e conjuntos agregando } \\
\text { outros produtos não abrangidos pelo } \\
\text { Regulamento. }\end{array}$ & & \\
\hline 1 & & & & $\begin{array}{l}\text { Produto apresentado em embalagem } \\
\text { especial que chame atenção por não } \\
\text { conter glúten? }\end{array}$ & SIM & NÃO \\
\hline
\end{tabular}

Fonte: Adaptado de Maciel (2012). 


\section{RESULTADOS}

\subsection{Análise da rotulagem dos produtos sem glúten à luz da legislação}

Foram analisados os rótulos e informações de 12 produtos da categoria de pães (todos os tipos de pães encontrados), 26 produtos da categoria de bolos (bolos, mini bolos, muffin e brownie), 92 da categoria de bolachas (bolachas, torradas e cookies) e 28 da categoria de massas alimentícias (macarrão e lasanha).

A primeira etapa da análise dos rótulos consistiu em avaliar se o conteúdo dos mesmos cumpriam as determinações da legislação sobre o glúten (BRASIL, 2003), a qual é bem sucinta, e norteia apenas sobre a necessidade de se colocar na embalagem dos alimentos industrializados a alegação "contém glúten" ou "não contém glúten", e se as mesmas estão em destaque, nítidas e de fácil leitura. Conforme mostra a Tabela 1, 100\% dos rótulos analisados revelaram cumprir a legislação no quesito apresentar de forma legível e em destaque a informação relativa à presença ou ausência de glúten.

Tabela 1. Proporção de rótulos que cumprem a legislação - 2019

\begin{tabular}{|c|c|c|c|c|}
\hline CATEGORIAS & PÃES & BOLOS & BOLACHAS & $\begin{array}{c}\text { MASSAS } \\
\text { ALIMENTÍCIAS } \\
\end{array}$ \\
\hline & \multicolumn{4}{|c|}{ CUMPRIMENTO (\%) } \\
\hline $\begin{array}{l}\text { O alimento possui descrito em sua } \\
\text { embalagem/no site se "não contém glúten"? }\end{array}$ & 100,0 & 100,0 & 100,0 & 100,0 \\
\hline $\begin{array}{l}\text { Os rótulos e embalagens/infs. técnicas do site } \\
\text { de compras dos produtos contêm a alegação } \\
\text { "não contém glúten" em caracteres em } \\
\text { destaque, nítidos e de fácil leitura? }\end{array}$ & 100,0 & 100,0 & 100,0 & 100,0 \\
\hline
\end{tabular}

A segunda etapa da análise avaliou a qualidade nutricional dos PSGs. Como se pode verificar na Tabela 2 , na categoria de pães, $100 \%$ dos produtos possuem densidade energética considerada elevada e $88,33 \%$ dos pães sem glúten possuem quantidade de sódio elevada, por outro lado, não se constatou teores elevados de ácidos graxos saturados e trans, na porção estabelecida.

$\mathrm{Na}$ categoria dos bolos, $100 \%$ dos produtos possuem densidade energética considerada elevada, 26,92\% tinham informação de ácidos graxos saturados acima do recomendado, e 11,54\% quantidades de sódio elevada. À semelhança dos pães também 
não se identificou nenhum tipo de bolo com ácidos graxos trans acima do parâmetro estabelecido.

Em relação à categoria das bolachas, a qualidade nutricional mostrou-se prejudicada por teores elevados de densidade energética, de ácidos graxos saturados e de sódio, em proporções variadas: 100\%, 70,65\% e 19,57\% respectivamente.

No que tange à categoria das massas alimentícias, as informações da rotulagem indicavam em $100 \%$ dos produtos analisados densidade energética acima do recomendado, e em 89,29\% dos produtos com sódio em nível considerado elevado.

Tabela 2. Percentual de produtos sem glúten com quantidades elevadas de densidade energética, ácidos graxos saturados e trans e sódio - 2019

\begin{tabular}{lcccc}
\hline \multicolumn{1}{c}{ CATEGORIAS } & PÃES & BOLOS & BOLACHAS & $\begin{array}{c}\text { MASSAS } \\
\text { ALIMENTÍCIAS }\end{array}$ \\
\hline $\begin{array}{l}\text { Possui DENSIDADE ENERGÉTICA } \\
\text { considerada ELEVADA? }\end{array}$ & 100,0 & 100,0 & 100,0 & 85,7 \\
\hline $\begin{array}{l}\text { Possui quantidade de ÁCIDOS GRAXOS } \\
\text { SATURADOS considerados elevados? }\end{array}$ & 0,0 & 26,9 & 70,6 & 0,0 \\
\hline $\begin{array}{l}\text { Possui quantidade de ÁCIDOS GRAXOS } \\
\text { TRANS considerados elevados? }\end{array}$ & 0,0 & 0,0 & 0,0 & 0,0 \\
\hline $\begin{array}{l}\text { Possui quantidade de SÓDIO considerada } \\
\text { elevada? }\end{array}$ & 83,3 & 11,54 & 19,6 & 17,9 \\
\hline
\end{tabular}

Na Tabela 3 consta o resultado de um terceiro tipo de análise feita em relação à possibilidade da presença de alguma informação especial e destacada acerca do produto no painel frontal, o que caracterizaria a presença de marketing nutricional.

Na categoria dos pães, bolos e bolachas, em 100\% dos produtos destaca-se a informação de que o produto "não contém glúten" em letras diferenciadas, grandes e que chamam atenção, ou em formato de símbolos com um trigo inserido na placa de proibido (Figura 1), informação que em princípio poderia estar localizada junto à lista dos ingredientes, no painel posterior da embalagem. E na categoria das massas alimentícias o percentual de informação especial é de $89,29 \%$ do total dos rótulos analisados. Além disso, outras alegações "diferenciadoras" apareceram como: "com sal marinho", "rico em fibras", "fonte de vitaminas", "produto vegano", "adoçado com stevia", "assado", "fonte de proteínas", as quais sugerem que o produto pode ser a melhor escolha pois apresenta características saudáveis. Todavia, como demonstrado pela análise da qualidade 
nutricional de tais produtos, eles possuem elevada densidade energética e elevado teor de sódio, desqualificando-os como produtos saudáveis cujo consumo deve ser estimulado.

Tabela 3. Percentual de produtos sem glúten que possuem "informação especial" no rótulo que enaltece a característica de não conter glúten - 2019

\begin{tabular}{lcccc}
\hline \multicolumn{1}{c}{ CATEGORIAS } & PÃES & BOLOS & BOLACHAS & $\begin{array}{c}\text { MASSAS } \\
\text { ALIMENTÍCIAS }\end{array}$ \\
\hline & \multicolumn{4}{c}{ SIM (\%) } \\
\hline $\begin{array}{l}\text { Produto apresentado em embalagem especial } \\
\text { que chame atenção por não conter glúten? }\end{array}$ & 100,0 & 100,0 & 100,0 & 89,3 \\
\hline
\end{tabular}

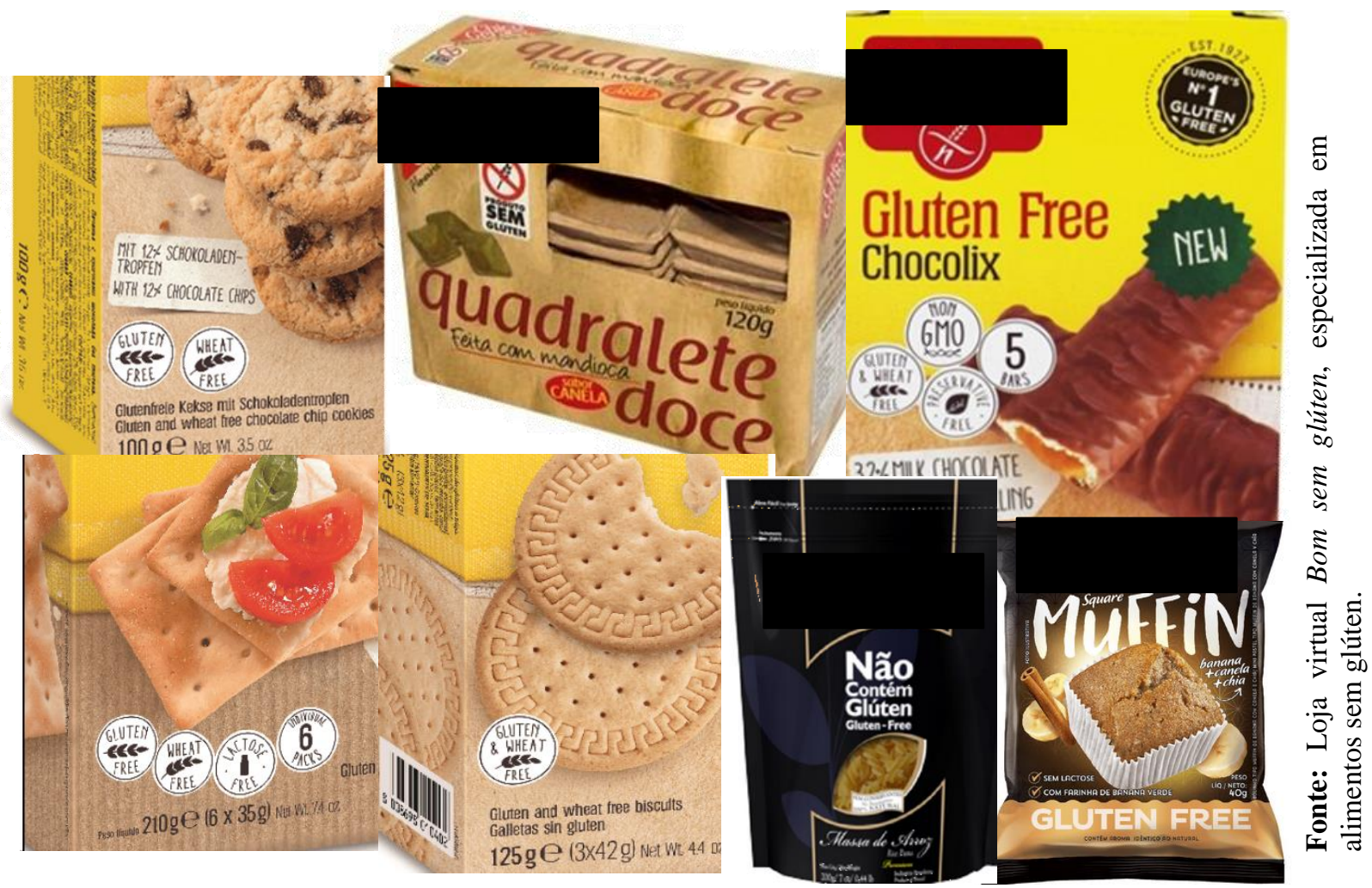

Figura 1. Parte frontal dos rótulos de alguns produtos sem glúten analisados e as alegações "não contém glúten" em diversos formatos.

A presença de informação especial na rotulagem de PSG caracteriza a presença de marketing nutricional, que não favorece uma escolha bem informada pelos consumidores. Além desse aspecto, é necessário destacar o diferencial em termos 
econômicos entre os produtos sem glúten e seus similares tradicionais. Para tanto foi realizado um exercício comparando a média de preço dos produtos avaliados à média dos produtos em sua versão tradicional (com glúten), apresentado na Tabela 4.

A relação dos preços de produtos sem glúten e a sua versão tradicional é de pelo menos 2 vezes mais, podendo chegar até 16 vezes dependendo da categoria, corroborando a hipótese de adoção de estratégia persuasiva pela indústria, o marketing nutricional, que ademais aproveita os vários mitos envolvendo o glúten, difundidos pelas redes sociais, fato que pode ser chamado de "marketing nutricional virtual".

Tabela 4. Média de preço de produtos sem glúten por categoria comparados à suas versões tradicionais - abril/2019

\begin{tabular}{|c|c|c|c|c|}
\hline PRODUTOS & Quantidade (g) & $\begin{array}{c}\text { Média de } \\
\text { Preço } \\
\text { (Tradicional) } \\
(\mathbf{R} \$) \\
\end{array}$ & \begin{tabular}{l}
\multicolumn{2}{c}{ Média de } \\
Preço (Sem \\
Glúten) $(\mathbf{R} \$)$
\end{tabular} & Razão \\
\hline PÃO & 500 & 5,13 & 35,48 & 6,9 \\
\hline BOLO & 40 & 2,81 & 5,02 & 1,8 \\
\hline BOLACHA & 130 & 1,99 & 17,5 & 8,8 \\
\hline TORRADA & 120 & 2,45 & 15,05 & 6,1 \\
\hline COOKIE & 40 & 1,89 & 4,09 & 2,2 \\
\hline MACARRÃO & 500 & 1,89 & 30,36 & 16,1 \\
\hline LASANHA & 200 & 2,69 & 23,26 & 8,6 \\
\hline $\begin{array}{l}\text { MACARRÃO } \\
\text { INSTANTÂNEO }\end{array}$ & 85 & 0,79 & 6,24 & 7,9 \\
\hline
\end{tabular}




\subsection{Percepção dos consumidores}

\subsubsection{Caracterização da amostra de consumidores}

A Tabela 5 apresenta as características geográficas, socioeconômicas e demográficas dominantes dos dois grupos em que se distribuiu os participantes da pesquisa: Segue $(n=32)$ e Não Segue $(n=22)$, verificando-se que os grupos são estatisticamente semelhantes em todos os aspectos analisados. O Anexo II apresenta a Tabela completa com a caracterização dos dois grupos.

Tabela 5. Características socioeconômicas e demográficas dos grupos Segue e Não segue uma dieta livre de glúten - 2019

\begin{tabular}{lrrr}
\hline Variáveis socioeconômicas e demográficas & Segue & Não Segue & Total Geral \\
\hline Feminino (\%) & 96,9 & 81,8 & 90,7 \\
\hline Idade média (anos) & 44,9 & 42,4 & 44,4 \\
\hline IMC $\left(\mathrm{Kg} / \mathrm{m}^{2}\right)$ & 26,3 & 24,5 & 25,2 \\
\hline Brancos (\%) & 25,0 & 22,7 & 24,1 \\
\hline Superior Incompleto ou mais (\%) & 84,4 & 77,3 & 81,5 \\
\hline Sudeste do Brasil (\%) & 62,5 & 95,5 & 75,9 \\
\hline Até 3 pessoas (\%) & 65,6 & 59,1 & 63,0 \\
\hline Renda individual entre R\$ 2863,00 a R $\$ 470,00(\%)$ & 15,6 & 22,7 & 18,5 \\
\hline Renda familiar maior do que R $9540,00(\%)$ & 28,1 & 45,5 & 35,2 \\
\hline
\end{tabular}

Obs.: Os testes de igualdade de médias ou de proporções não rejeitaram a Hipótese nula de igualdade a $5 \%$.

Participaram da pesquisa qualitativa 54 pessoas, sendo 90,7\% do sexo feminino, com média de Índice de Massa Corporal (IMC) de 25,2, $\mathrm{kg} / \mathrm{m}^{2}$ e de idade de 44,4 anos, e menos de um quarto declarou-se de cor branca. Em relação ao tamanho das famílias, $63 \%$ dos participantes alegam viver em residências com até 3 moradores, a maioria é residente no sudeste do Brasil (75,9\%). Em termos de renda individual a maior proporção dos participantes se auto classificaram na faixa de $\mathrm{R} \$ 2,86$ mil a $\mathrm{R} \$ 4,77$ mil (18,5\%), ao passo que em termos de renda familiar, a maior proporção declarou pertencer à faixa mais elevada $\mathrm{R}$ \$ 9,54 mil ou mais (35,2\%). Os testes de igualdade de médias ou de proporções 
não rejeitaram a hipótese nula de igualdade ao nível de 5\%, das características socioeconômicas, demográficas e geográficas dos dois grupos.

No que tange ao problema de saúde que levou os que seguem a aderir a uma DLG, um terço informou ser por autodiagnóstico e um terço por diagnóstico de outros problemas relacionados ao glúten, que não a DC, realizado por profissional da saúde, o restante não relacionou qualquer problema de saúde como razão para adoção de uma DLG. 


\subsubsection{A percepção dos consumidores sobre os PSGs industrializados - Análise das respostas objetivas}

No questionário virtual, havia cinco questões fechadas, realizadas a fim de entender o comportamento dos consumidores ante os rótulos e as alegações "CONTÉM GLÚTEN" e "NÃO CONTÉM GLÚTEN", e a sua visão a respeito da DLG. Os resultados são apresentados na forma de gráficos segundo os dois grupos de participantes: SEGUE (GS) e NÃO SEGUE (GNS) a dieta livre de glúten (DLG).

O Gráfico 1 é referente à pergunta: Em suas compras de alimentos, você costuma ler o rótulo dos produtos? Para a resposta "Sim, na primeira compra", os grupos GS $(16 \%)$ e GNS (14\%) se equiparam em um baixo percentual. Na resposta "Sim, todas as vezes", o GS (72\%) predomina, em contrapartida, as respostas "Sim, às vezes" (50\%) e "Não" (9\%) do GNS, demonstrando que o grupo que segue uma DLG tem mais preocupação em buscar informações sobre o produto na rotulagem, em relação àqueles que não seguem a DLG.

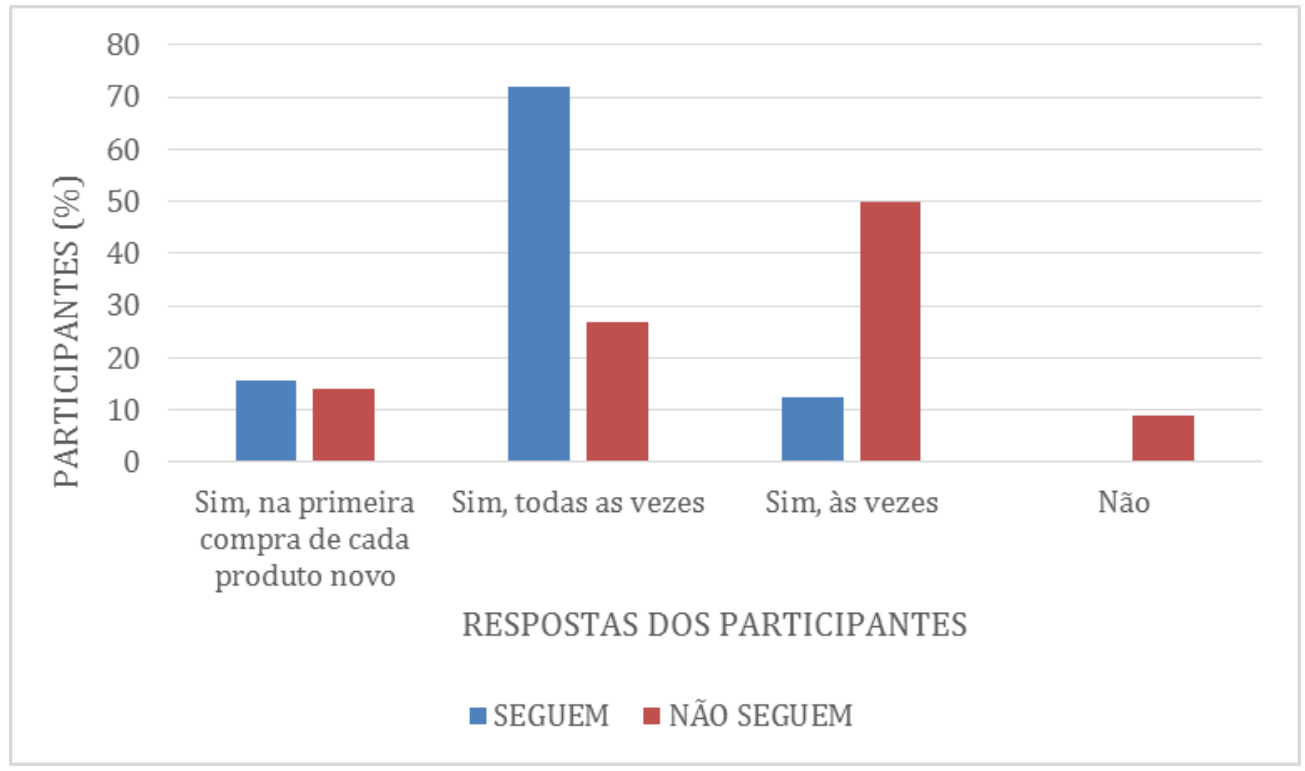

Gráfico 1. Frequência de leitura do rótulo de alimentos, segundo os grupos Segue e Não Segue a DLG

O Gráfico 2 corresponde à pergunta: "Você adquire um alimento quando identifica que ele CONTÉM GLÚTEN?”. Como esperado, a maior proporção dos participantes do GS deu como resposta "Não" (66\%) e o GNS, em sua maioria, respondeu "Sim" (59\%) e "Tanto faz, não olho isso" (18\%), indicando que realmente os indivíduos 
que seguem uma DLG evitam esse tipo de alimento, apesar de ainda haver uma parte do grupo que não os evita sistematicamente; e os que não seguem, consomem ou não se importam com essa classificação.

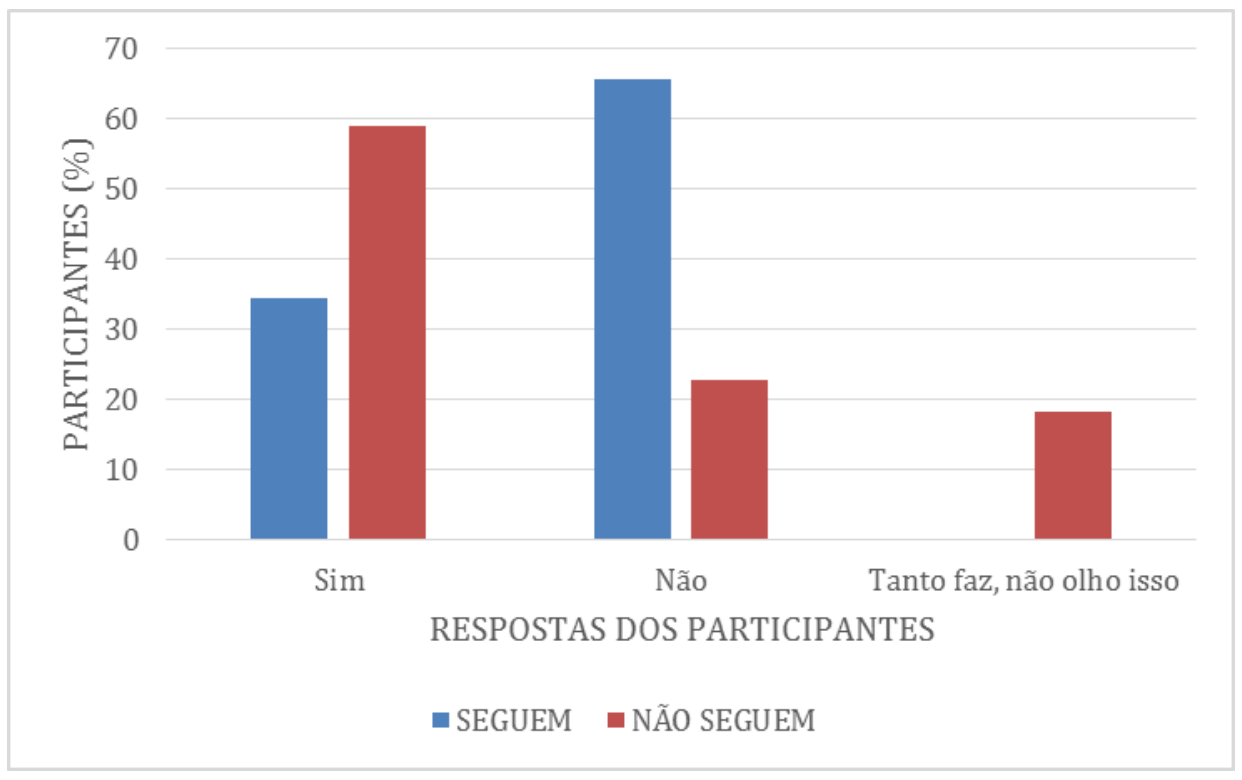

Gráfico 2. Intenção de aquisição de produto que Contém Glúten, segundo os grupos Segue e Não Segue a DLG

A distribuição das respostas à pergunta: "Você adquire um alimento quando identifica que ele NÃO CONTÉM GLÚTEN? ” está apresentada no Gráfico 3. Para o GS predominou a resposta "Sim" (100\%) e os percentuais de respostas dos GNS foram distribuídas nas três categorias, "Sim" (72\%), "Não" (5\%) e "Tanto faz, não olho isso" (23\%), indicando que ambos os grupos consomem alimentos sem glúten, independentemente de ser adepto ou não à dieta restritiva. 


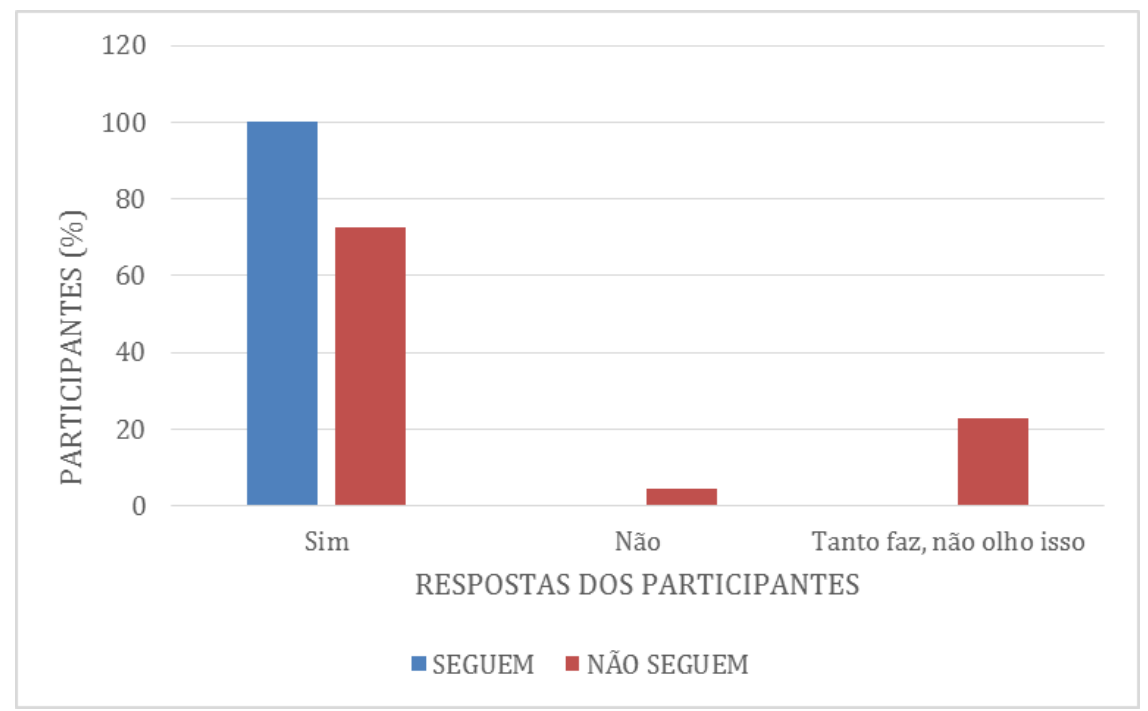

Gráfico 3. Intenção de aquisição de produto que Não Contém Glúten, segundo os grupos Segue e Não Segue a DLG

O Gráfico 4 se refere a frequência de consumo de alimentos com glúten em ambos os grupos, com o objetivo de entender se os indivíduos com dieta restrita sempre seguem o mesmo padrão. Os dois grupos (GS, 31\% e GNS, 32\%) têm percentuais semelhantes quanto a resposta "Às vezes abro uma exceção e consumo alimentos COM GLÚTEN", mas em geral, o maior percentual da resposta "Muitas vezes abro uma exceção e consumo alimentos COM GLÚTEN" é do GNS (55\%), e a "Nunca abro uma exceção (sempre consumo alimentos SEM GLÚTEN” é do GS (53\%).

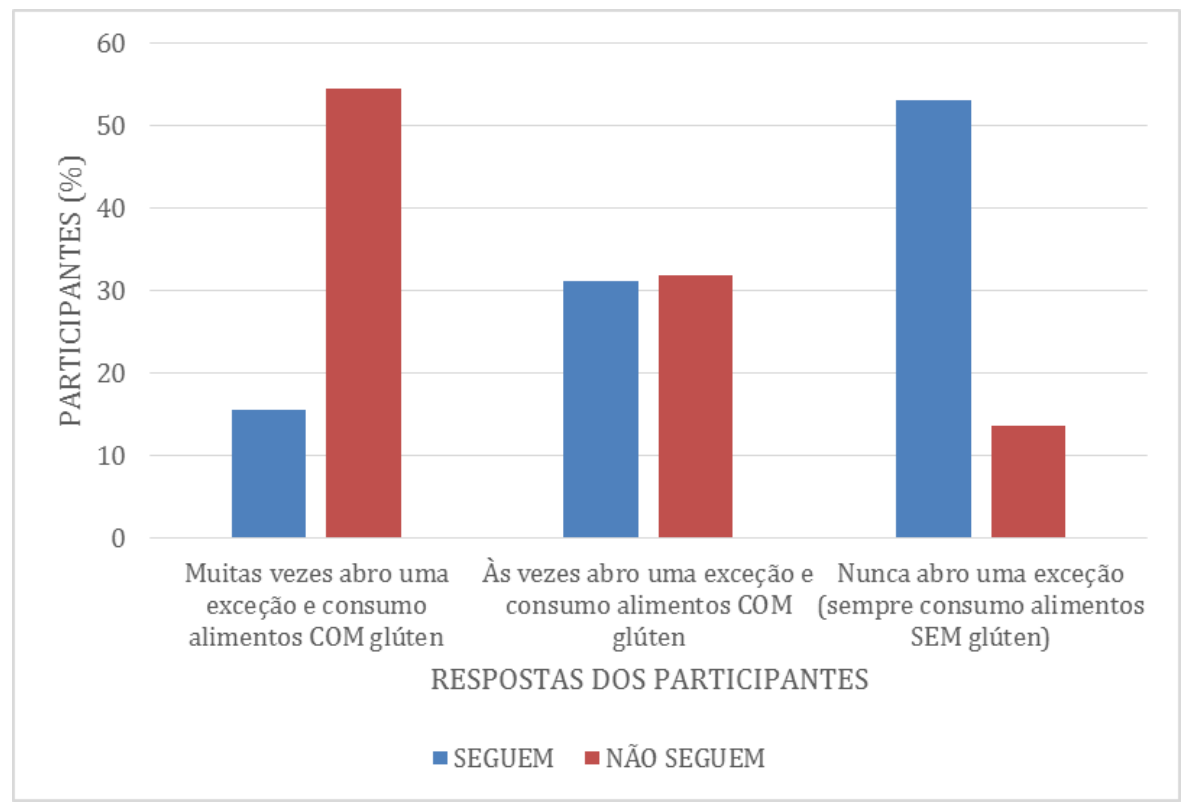

Gráfico 4. Consumo de alimentos com glúten segundo os grupos Segue e Não Segue a DLG 
O Gráfico 5 permite comparar as respostas dos dois grupos para a pergunta "Onde você obteve informações sobre o glúten?”, que denota que o GS busca as informações mais comumente (os participantes podiam assinalar mais de uma resposta, não totalizando em 100\%), na Internet (81\%), com Profissional da Saúde (66\%), Redes Sociais (56\%) e Livros (44\%), ao passo que o GNS, embora também utilize como fontes de informação a Internet (50\%) e Redes Sociais (41\%), elevada proporção é obtida pela Televisão (32\%) e por Outros meios (conversas com conhecidos, ou no trabalho ${ }^{4}$ ).

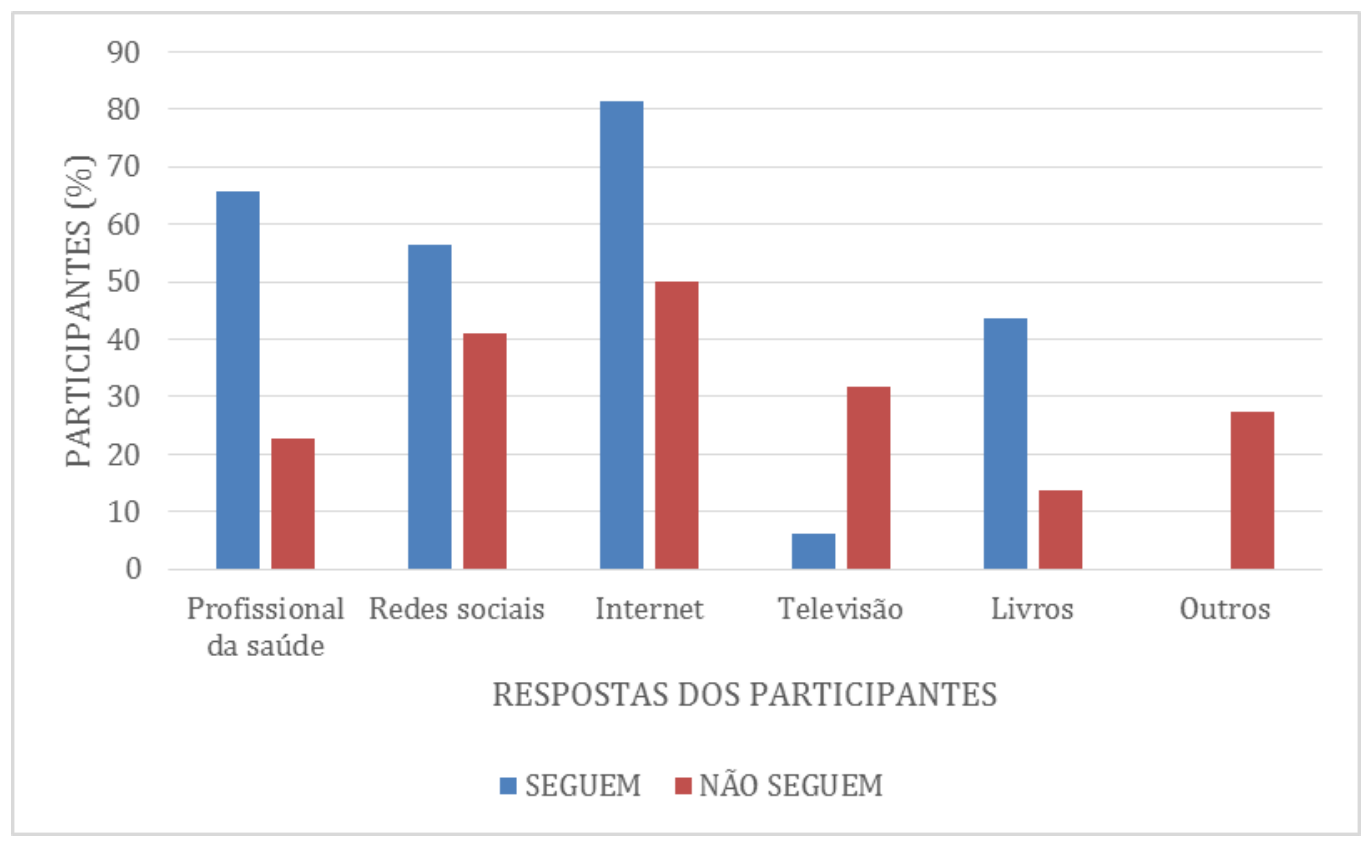

Gráfico 5. Meios de adquirir informações sobre glúten segundo os grupos Segue e Não Segue a DLG

\footnotetext{
${ }^{4}$ Quem trabalha com importação de alimentos acaba tendo contato com essas informações, pois a ANVISA determina que produtos importados tenham alegação no rótulo alertando sobre a presença de glúten no produto.
} 


\subsubsection{A percepção dos consumidores sobre os PSG industrializados - Análise do Sujeito do Discurso Coletivo}

No mesmo questionário virtual, também foram propostas 4 perguntas abertas sobre aspectos relacionados aos produtos sem glúten (PSG) industrializados, visando investigar como as informações disponibilizadas pelos fabricantes na rotulagem de seus produtos eram interpretadas pelos consumidores que optaram por seguir (GS) ou não seguir (GNS) uma dieta livre de glúten (DLG). Na sequência, são apresentados os discursos construídos a partir das ideias centrais extraídas das respostas.

A Pergunta 1, (Você segue ou tem/teve vontade de seguir uma dieta sem glúten? Se sim, por quê?), teve o objetivo principal de classificação dos grupos em relação a seguir ou não uma dieta sem glúten, bem como de entender se alguém que não segue já teve vontade de seguir, e os motivos que levam a seguir ou ter vontade de seguir a DLG. (Tabelas 6 e 7).

A maior parte dos indivíduos do GS (44\%) seguem uma dieta sem glúten por sentir melhoria na qualidade de vida, reduzindo sintomas de doenças como Tireoide de Hashimoto, ou outros como indisposição intestinal, inchaço, dores de cabeça, alergias e infecções na pele; $28 \%$ por acreditarem ser mais saudável, pela digestão fácil, menor índice glicêmico, redução de quadros de infecção urinária e dor de garganta, e ingestão de menos alimentos ultraprocessados; $9 \%$ motivados a entender as dificuldades das pessoas com DC com as quais moram e 19\% disseram que seguem, mas não falaram o motivo.

Já para os indivíduos do GNS, verificou-se que 73\% relatam haver um exagero em torno do glúten, ou inviabilidade de se seguir esse tipo de dieta restritiva; $14 \%$ acreditam ser mais saudável e ideal, até sendo possível perder peso, mas é difícil; 5\% alegaram sintomas ruins ao consumir especificamente o trigo, afirmando ser "o causador das inflamações do organismo"; 5\% alegaram ter vontade, mas não explicaram o motivo e $5 \%$ responderam que não sabiam. 
Tabela 6. Você segue ou tem/teve vontade de seguir uma dieta sem glúten? Se sim, por $q u \hat{e} ?$ - Grupo SEGUE

\begin{tabular}{llcc}
\hline Categoria & & Respostas & $\%$ \\
\hline \multirow{2}{*}{ A } & SINTOMAS RUINS AO & 14 & 44 \\
B & CONSUMIR GLÚTEN & 9 & 28 \\
& SAUDÁVEL & 3 & 9 \\
C & PESSOAS EM CASA COM & 6 & 19 \\
D & DC & 32 & 100 \\
\hline Total & & & \\
\hline
\end{tabular}

Tabela 7. Você segue ou tem/teve vontade de seguir uma dieta sem glúten? Se sim, por quê? - Grupo NÃO SEGUE

\begin{tabular}{llrr}
\hline Categoria & & Respostas & $\%$ \\
\hline A & NÃO & 16 & 73 \\
B & SAUDÁVEL & 3 & 14 \\
& SINTOMAS RUINS AO & 1 & 5 \\
C & CONSUMIR GLÚTEN & 1 & 5 \\
D & TENHO VONTADE, SEM & 1 & 5 \\
E & NX̃LICAÇÃO SEI & 22 & 100 \\
\hline Total & & & \\
\hline
\end{tabular}

Em seguida, os discursos referentes as ideias centrais do GS e GNS das respostas encontradas na pergunta 1 .

GRUPO SEGUE:

\section{DSC A: SINTOMAS RUINS AO CONSUMIR GLÚTEN}

“Eu sigo por ter diagnóstico de intolerância ao glúten não celíaca confirmado, e outros problemas que a presença do glúten piora, como a tireoide de Hashimoto, alergia, 
prurido e infecções na pele. Faz 10 anos que parei de consumi-lo, e os meus sintomas só voltam a aparecer se eu consumir ou me contaminar com glúten. Sinto melhor qualidade de vida, sem dores de cabeça, inchaço e indisposição intestinal.

\section{DSC B: SAUDÁVEL}

"Sigo 101\%, pois é uma dieta de digestão mais fácil e menor índice glicêmico. Sinto que tenho mais qualidade de vida, por acabar comendo menos industrializados, de modo geral, e até as infecções urinárias e de garganta que eram rotineiras, acabaram”.

\section{DSC C: PESSOAS EM CASA COM DC}

"Sim, todos aqui em casa tentamos, porque minha filha, meu filho e meu marido são celíacos, e pretendo entender as dificuldades que eles passam no dia a dia, mas as outras crianças não se adaptaram à alimentação diferenciada”.

\section{GRUPO NÃO SEGUE:}

\section{DSC A: NÃO}

“Nunca me preocupei com isso, na verdade acho que há um exagero em torno do assunto e não é viável seguir uma dieta sem glúten com o meu tipo de trabalho, que não tem rotina definida para a escolha dos produtos. Por exemplo, em festas, restaurante e na nossa casa é difícil não consumir glúten. Como os sintomas da reação são conhecidos pela nossa família, podemos administrar o consumo para não ser feito sempre.

\section{DSC B: SAUDÁVEL}

"Seria o ideal, pois apesar de ser uma dieta difícil, funciona e inclusive dá para perder uns quilinhos".

A Pergunta 2 (Sob a perspectiva de saúde, qual a sua opinião sobre alimentos que contêm glúten?), teve o objetivo de avaliar o que os consumidores sabem a respeito dos 
alimentos que contém glúten. Predominantemente, ambos os grupos acreditam que são alimentos prejudiciais à saúde $(\mathrm{GS}=53 \%$ / GNS $=45 \%)$ por motivos intestinais e extra intestinais, por serem alimentos muito processados e refinados, pela associação ao ganho de peso e pela transformação destes alimentos em açúcar no organismo (Tabelas 8 e 9).

Proporcionalmente, os grupos também acreditam que o glúten faz mal apenas aos celíacos, o GS (19\%) afirmou que estes alimentos são "para aqueles que o organismo não o aceita". Esse posicionamento foi também afirmado pelo GNS (14\%), que salientou que tudo em excesso faz mal, “...e se houver intolerância é grave o consumo”.

O GNS se mostrou indiferente (14\%) à presença do glúten, por não terem problemas, alegando que "podem ser tão saudáveis como os que não contém glúten”.

Os grupos afirmaram ainda serem alimentos "mais gostosos" e com preço baixo $(\mathrm{GS}=3 \% / \mathrm{GNS}=9 \%$, além de serem mais acessíveis, pois são encontrados com facilidade.

Tabela 8. Sob a perspectiva de saúde, qual a sua opinião sobre alimentos que contêm glúten? - Grupo SEGUE

\begin{tabular}{llrr}
\hline Categoria & & Respostas & $\%$ \\
\hline A & PREJUDICIAIS À SAÚdE & 17 & 53 \\
B & FAZEM MAL À CELÍACOS & 6 & 19 \\
C & SABOR E CUSTO & 1 & 3 \\
D & RESP. SEM SENTIDO & 7 & 25 \\
\hline Total & & 32 & 100 \\
\hline
\end{tabular}


Tabela 9. Sob a perspectiva de saúde, qual a sua opinião sobre alimentos que contêm glúten? - Grupo NÃO SEGUE

\begin{tabular}{llrr}
\hline Categoria & & Respostas & $\%$ \\
\hline A & PREJUDICIAIS A SAÚDE & 10 & 45 \\
B & INDIFERENÇA & 3 & 14 \\
C & FAZEM MAL À CELÍACOS & 3 & 14 \\
D & SABOR E CUSTO & 2 & 9 \\
E & SEM CONHECIMENTO/OPINIÃOO & 3 & 14 \\
F & RESP. SEM SENTIDO & 1 & 5 \\
\hline Total & & 22 & 100 \\
\hline
\end{tabular}

Seguem os discursos referentes às ideias centrais do GS e GNS das respostas à pergunta 2.

\section{GRUPO SEGUE:}

\section{DSC A: PREJUDICIAIS À SAÚDE}

"Não devo consumir, pois é um veneno para a saúde tanto de celíacos, como não celíacos, por não termos enzimas suficientes para digestão. Sendo assim, sinto desconforto em todos os sentidos, fico mais lento e desconcentrado; desencadeia minha desidrose, psoríase e refluxo; sinto desconforto gastrointestinal como estufamento e inchaço, além de virar açúcar no organismo".

\section{DSC B: FAZEM MAL À CELÍACOS}

"Eu acho que devem ser utilizados por quem não tem qualquer problema com ele, pois são alimentos normais. Existem algumas linhas de pesquisa que falam que ele faz mal a todas as pessoas, mas acredito que o glúten só faz mal para aqueles que o organismo não o aceita". 
GRUPO NÃO SEGUE:

\section{DSC A: PREJUDICIAIS À SAÚDE}

"Tem me feito muito mal, talvez por serem menos saudáveis, pois são alimentos com farinha branca; além de que muitos são ultraprocessados e com excesso de glúten nas sementes transgênicas, principalmente do trigo. Eles me deixam a sensação de cheio e dificultam o emagrecimento, mas só são contraindicados para intolerantes”.

\section{DSC B: INDIFERENÇA}

"Sou indiferente. porque no meu dia a dia não tenho problemas com o glúten, e não dou importância para isso, estes alimentos podem ser tão saudáveis como os que não contém glúten”.

\section{DSC C: FAZEM MAL À CELÍACOS}

“Como eu não tenho problemas com glúten, consumindo moderadamente não acredito que faça mal, do contrário, tudo em excesso faz mal à saúde. E se houver intolerância é grave o consumo”.

\section{DSC D: SABOR E CUSTO}

"O glúten é um alimento de baixo custo, por isso está presente em muitos alimentos no Brasil e em todo o mundo, além disso, eu acho que os alimentos que contém glúten são muito mais gostosos do que os que não o contém”.

A Pergunta 3, (O que você pensa de um alimento cujo rótulo está escrito "não contém glúten"?) avaliou a percepção dos consumidores frente à alegação "Não contém glúten" no rótulo dos alimentos (Tabelas 10 e 11). 53\% do GS e 27\% GNS acreditam estar relacionada a alimentos mais saudáveis, com menos malefícios, menor valor energético, além de ser "limpo, puro e com menor índice glicêmico, e menos farinha de trigo". Essas interpretações não são corretas, uma vez que um alimento sem glúten pode 
ter índice glicêmico e valor energético elevados, devem ser limpos segundo o critério de qualidade aplicado em sua fabricação, e não podem conter farinha de trigo.

Ambos os grupos (GS = 19\%/ GNS = 9\%) também desacreditam se de fato não possuem glúten em sua composição, e acabam recorrendo ao SAC das empresas para confirmar esta informação “...pois nem sempre é 100\% sem glúten”. Apenas acreditam com tranquilidade se forem produtos que já consumiram.

A maior porcentagem do GNS (32\%) acredita que é uma informação importante para celíacos, e apenas $6 \%$ do GS compartilha da mesma opinião.

Menos de um quinto do GS acredita que são alimentos mais seguros, por poderem ingerir sem a preocupação de contaminação, porém no GNS existem os participantes que pensam serem alimentos prejudiciais à saúde (5\%), pelo que ouviram falar, e não por terem testado; os que acham a composição e qualidade ruins (18\%), por serem mais secos e "esfarelentos", não conter farinha branca, trigo e centeio, e a alegação ser apenas uma estratégia de marketing para convencer que são alimentos melhores, e também os que não se importam, uma vez que o relevante é a composição do alimento e não se contém ou não glúten (9\%).

Tabela 10. O que você pensa de um alimento cujo rótulo está escrito "não contém glúten"? - Grupo SEGUE

\begin{tabular}{llrr}
\hline Categoria & & Respostas & $\%$ \\
\hline A & SAUDÁVEL & 17 & 53 \\
B & DÚVIDA SOBRE A AUSÊNCIA & 6 & 19 \\
C & SEGURO & 6 & 19 \\
& IMPORTANTE PARA & 2 & 6 \\
D & CELÍACOS & 1 & 3 \\
E & RESP. SEM SENTIDO & 32 & 100 \\
\hline Total & & & \\
\hline
\end{tabular}


Tabela 11. O que você pensa de um alimento cujo rótulo está escrito "NÃO CONTÉM GLÚTEN"? - Grupo NÃO SEGUE

\begin{tabular}{llrr}
\hline Categoria & & Respostas & $\%$ \\
\hline A & IMPORTANTE PARA CELÍACOS & 7 & 32 \\
B & SAUDÁVEL & 6 & 27 \\
C & COMPOSIÇÃO/QUALIDADE & 4 & 18 \\
D & NÃO IMPORTA & 2 & 9 \\
E & DÚVIDA SOBRE A AUSÊNCIA & 2 & 9 \\
F & PREJUDICIAL À SAÚdE & 1 & 5 \\
\hline Total & & 22 & 100 \\
\hline
\end{tabular}

As respostas à pergunta 3 do GS e GNS permitiram a construção dos discursos coletivos apresentados a seguir.

GRUPO SEGUE:

\section{DSC A: SAUDÁVEL}

"Penso que é um alimento, limpo, puro, com menor índice glicêmico e menos farinha de trigo, e não vou sofrer passando mal depois, pois agride menos o meu organismo, ajudando a manter minha saúde”.

\section{DSC B: DÚVIDA SOBRE AUSÊNCIA}

"Deveria ser um alimento totalmente isento de glúten, mas às vezes acho mentirosa a informação, pois leio os alergênicos, e têm muitos rótulos errados. Se é um produto novo de uma marca que já confio, compro sem problemas, porém de marcas que não tenho costume de comprar, eu adquiro o produto e só consumo quando há resposta de ausência de glúten pelo SAC da empresa”. 


\section{DSC C: SEGURO}

"Sei que é seguro e confio que não contém glúten. Sendo assim, posso ingerir, por acreditar que não tenha passado por nenhum tipo de contaminação, principalmente a cruzada”.

\section{DSC D: IMPORTANTE PARA CELÍACOS}

"Se está no rótulo, está pensando no consumidor que não pode consumi-lo, sendo seguro para quem tem algum problema ao ingerir glúten”.

GRUPO NÃO SEGUE:

\section{DSC A: IMPORTANTE PARA CELÍACOS}

“Apenas uma informação extremamente importante para pessoas que não podem consumi-lo, como a minha filha, sendo uma informação específica para quem tem intolerância ao glúten”.

\section{DSC B: SAUDÁVEL}

"Respiro aliviada, pois não terei que ficar lendo a composição toda, eu confio no que está escrito. Além de ser um produto com menos malefícios e calorias, sendo assim mais saudável, no entanto, talvez mais caro”.

\section{DSC C: COMPOSIÇÃO/QUALIDADE}

"Penso que pode ser apenas uma estratégia de marketing do fabricante, para fingir ser saudável, mas na verdade só é um alimento que não tem farinha branca, é mais seco e esfarelento, e não contém trigo, centeio e etc". 


\section{DSC D: NÃO IMPORTA}

"Não dou importância, pois o que interessa é a composição do alimento, e não se contém ou não glúten".

\section{DSC E: DÚVIDA SOBRE AUSÊNCIA}

“Olho com atenção, pois nem sempre é 100\% sem glúten”.

A Pergunta 4 (Se você precisasse perder peso, você compraria alimentos com ou sem glúten? Por quê?) analisa a percepção dos consumidores a respeito da relação entre a perda de peso com o consumo de alimentos sem glúten (Tabelas 12 e 13).

Em sua maioria, os grupos ( $\mathrm{GS}=56 \% / \mathrm{GNS}=50 \%$ ) acreditam que os alimentos sem glúten estão associados à perda de peso, em decorrência da retenção de líquidos causando inchaço, por ter maior valor energético, por ser transformado em açúcar no organismo, e impedir o desenvolvimento de massa magra.

Cerca de 30\% do GS e GNS assumem que são indiferentes, pois o aumento de peso acontece em decorrência de uma dieta desequilibrada, que pode conter ou não glúten, uma vez que ambas as versões podem ser calóricas, e algumas sem glúten são ainda mais.

E 14\% apenas do GNS não sabem responder, e acreditam ser melhor consultar uma nutricionista ou um médico para estabelecer quais alimentos são melhores para esta finalidade.

Tabela 12. Se você precisasse perder peso, você compraria alimentos com ou sem glúten? Por quêe? - GRUPO SEGUE

\begin{tabular}{llrr}
\hline \multicolumn{1}{c}{ Categoria } & Respostas & $\%$ \\
\hline A & SEM GLÚTEN & 18 & 56 \\
B & INDIFERENTE & 10 & 31 \\
C & RESP. SEM SENTIDO & 4 & 13 \\
\hline Total & & 32 & 100 \\
\hline
\end{tabular}


Tabela 13. Se você precisasse perder peso, você compraria alimentos com ou sem glúten? Por quê? - Grupo NÃO SEGUE

\begin{tabular}{llrr}
\hline Categoria & & Respostas & $\%$ \\
\hline A & SEM GLÚTEN & 11 & 50 \\
B & INDIFERENTE & 7 & 32 \\
C & NÃO SEI & 3 & 14 \\
D & RESP. SEM SENTIDO & 1 & 5 \\
\hline Total & & 22 & 100 \\
\hline
\end{tabular}

As respostas à pergunta 4 do GS e GNS, permitiram a elaboração de discursos coletivos, conforme podem ser examinados na sequência.

\section{GRUPO SEGUE:}

\section{DSC A: SEM GLÚTEN}

"Sempre sem glúten, porque tenho intolerância, mesmo que sem diagnóstico, mas o glúten inflama e retém líquido me causando inchaço na barriga. Estava muito acima do peso, e com a dieta sem glúten consegui perder o excesso, pois ao ingeri-lo, este é metabolizado virando açúcar no nosso sangue, dificultando a perda de peso; e ainda posso ganhar massa magra. Comida de verdade não tem glúten, eu prefiro alimentos in natura como batatas, do que TACC (trigo, aveia, cevada e centeio)".

\section{DSC B: INDIFERENTE}

“Tanto faz, retirada do glúten não emagrece ninguém. Se fosse para emagrecer, eu seguiria uma dieta equilibrada indicada por nutricionista e diminuiria o consumo de farináceos refinados em geral, pois o excesso de peso não está relacionado diretamente ao glúten, mas à alimentação não balanceada. Eu faço restrição ao glúten por conta de 
outros conceitos, mas procuro equilibrar os alimentos com e sem glúten, porque ambas as versões são calóricas, e tem algumas sem glúten que são ainda mais”.

GRUPO NÃO SEGUE:

DSC A: SEM GLÚTEN

"Para mim só serve sem glúten, por ser melhor, ajudando no processo de emagrecimento, por evitar o inchaço e reduzir calorias. Sou a prova viva que sem o trigo perdi muito peso, e tenho a impressão que a minha gordura localizada na barriga reduziu”.

\section{DSC B: INDIFERENTE}

“Ambos, sem distinção, pois não acho que engordam, o que faz perder peso é comer menos, e reduzir ou cortar o carboidrato, evitar alimentos com farinha branca como o trigo, no entanto sei que consumindo de forma moderada, não me engordariam”.

\section{DSC C: NÃO SEI}

"Não sei avaliar se ajuda ou prejudica a perda de peso, teria que consultar um nutricionista/médico para eles me indicarem os melhores produtos".

De maneira geral, os consumidores possuem uma ideia positiva em relação aos PSG, grande parte alegando sentir certo alívio em consumir produtos que não contém glúten em sua composição, com relatos de serem alimentos mais limpos, seguros, saudáveis e não ocasionarem diversos tipos de reações adversas, dentre elas problemas intestinais, inchaço e aumento de peso.

Além da percepção pessoal, ficou evidenciado o papel que a internet representa como principal forma de obtenção da informação destes produtos, em ambos os grupos, evidenciando a influência do que denominamos aqui de "marketing nutricional virtual" em torno de mitos envolvendo o glúten como um nutriente não saudável. Tal visão coletiva, adicionalmente, é aproveitada pela indústria em suas estratégias de marketing 
utilizando "informações especiais" nos painéis principais de seus rótulos, estimulando a venda de produtos não necessariamente mais saudáveis, mas, de modo geral, mais caros sem contribuir para que os consumidores façam escolhas mais bem informadas. 


\section{DISCUSSÃO}

No Brasil, a LF 10.674/2003 exige que todos os produtos industrializados contenham a alegação sobre a existência ou não de glúten no alimento, porém, na legislação não há descrição do local do rótulo onde esta alegação pode ser afirmada, sendo apenas ressaltado que deve ser com nitidez, como descrito no $\S 1^{\circ}$ " $A$ advertência deve ser impressa nos rótulos e embalagens dos produtos respectivos assim como em cartazes e materiais de divulgação em caracteres com destaque, nítidos e de fácil leitura."

Os produtos aqui avaliados apresentaram alegação da ausência de glúten no painel frontal da embalagem não apenas de modo legível, mas em grande destaque e muitas vezes acompanhada de símbolos que acabam por induzir o consumidor a acreditar que é um produto mais saudável. A apresentação do trigo em uma placa de proibido, por exemplo, nega a importância de um alimento, que foi descoberto na região do Sudeste Asiático, há 10.000 anos, numa região chamada de "Crescente Fértil”, que se agrega como matéria prima em muitas preparações, e é fundamental na alimentação humana até os dias atuais (GRECO, 1997).

De modo geral, os produtos naturalmente sem glúten costumam ter baixo valor energético, de modo que uma DLG quando seguida rigidamente, tende a gerar déficit energético favorecendo a perda de peso. Em outras palavras, não é a ausência de glúten o responsável pela perda de peso, mas a redução do consumo de alimentos com elevada densidade energética. Assim, é um mito que os produtos sem glúten industrializados, ou seja, os mesmos produtos que contêm glúten, com seus ingredientes substituídos por outros que não contêm glúten, contribuam para a perda de peso, sendo que podem conter a mesma qualidade nutricional de suas versões tradicionais, ou serem inferiores como demonstrado por Wu et al. (2015).

No presente trabalho, não houve comparação da qualidade nutricional dos PSG com o similar tradicional, mas os parâmetros utilizados na análise permitiram verificar que a grande maioria dos PSG (pães, bolos, bolachas e massas alimentícias) continha elevada densidade energética e teor de sódio, e alguns, como os da categoria de bolos e bolachas, quantidades elevadas de ácidos graxos saturados, o que regularmente consumidas em uma dieta desequilibrada levam ao aumento de peso e a outras complicações à saúde. 
Mariani et al. (1998) constataram o alto consumo de bolachas sem glúten por adolescentes celíacos, itens também ricos em ácidos graxos saturados como suas versões tradicionais. Atualmente, apesar do desenvolvimento tecnológico aplicado à produção de alimentos sem glúten estar mais avançado, ainda são encontrados muitos PSG com elevada densidade energética, ácidos graxos saturados, sal e baixo teor proteico (THEETHIRA et al., 2014; MELINI et al., 2019).

E embora atualmente haja mais facilidade em encontrar este tipo de produto, a acessibilidade e a variedade ainda são limitadas sobretudo a locais de alto padrão, pouco convencionais; além do preço elevado. Em um mesmo local, o diferencial de preços variou de 2 a 16 vezes mais que o valor das versões tradicionais, a depender da categoria considerada. Allen e Orfila (2018), em um estudo transversal sobre disponibilidade e custo de PSGs em quatro lojas virtuais no Reino Unido, afirmaram a menor acessibilidade e o preço mais elevado dos produtos sem glúten em comparação a seus similares com glúten.

Mesmo com essas dificuldades, mais de $50 \%$ dos participantes desta pesquisa seguem uma DLG por sentirem sintomas ruins com o consumo de produtos com glúten, por terem alguém da família que é celíaco, ou por acreditarem que tais produtos contribuem para uma melhor qualidade de vida, e para a manutenção do peso corporal, uma vez que acreditam que os produtos com glúten são muito processados e refinados, e se transformam em açúcar no organismo. Este último é outro mito, uma vez que toda fonte de carboidrato, com ou sem glúten, será metabolizada e transformada em açúcar após a digestão (Bruce, 2006).

No que tange às razões que levam as pessoas a aderirem a uma DLG, sem diagnóstico de DC, existem estudos sobre a percepção de consumidores de DLG conduzidos na Argentina, Colômbia e em El Salvador que identificaram motivos semelhantes aos encontrados no presente estudo, como o controle de peso, e a percepção de que são produtos mais saudáveis e que melhoram a digestão (CABRERA-CHÁVEZ, et al. 2016; CABRERA-CHÁVEZ, et al. 2017; ONTIVEROS et al. 2018). Dunn et al. (2014) também reforçam a crença de perda de peso e saudabilidade pelo relato de $57 \%$ dos participantes avaliados em seu estudo conduzido na University of Florida sobre a influência dos rótulos de produtos sem glúten e crenças sobre saúde com a DLG. 
Até aqueles que não seguem uma DLG também acreditam que o consumo de produtos com glúten é prejudicial à saúde, e manifestam a dúvida ao utilizar a palavra “talvez” em relação ao caráter saudável dos PSGs. Um outro elemento introduzido no tema foi a produção com sementes transgênicas, associada ao período de aumento dos casos da DC. Contudo, de acordo com Kasarda (2013), a partir da metade do século XX, não houve alteração na quantidade de glúten do trigo, não podendo ser estabelecida uma relação de causalidade neste contexto; é certo que algumas práticas agronômicas atuais podem alterar a quantidade de glúten nos alimentos, porém, este aumento apenas se torna mais tóxico àqueles que possuem intolerância, e não desencadeiam processo inflamatório nos que não têm suscetibilidade genética.

Tal preocupação em relação a alegação de conter ou não glúten foi refletida na elevada proporção de indivíduos os quais seguem uma DLG (72\%) e realizam a leitura de rótulos em todas as compras, não havendo nenhuma parte do público alegando não ler. Gomes e Cyrillo (2006), em um estudo sobre análise de rótulos e qualidade da alimentação com mulheres da região Leste de São Paulo, identificaram um percentual semelhante de $60 \%$ que liam os rótulos antes da compra. Este comportamento foi associado positiva e estatisticamente com a qualidade da alimentação, à semelhança do observado no presente estudo entre os participantes que seguem uma DLG. A mesma situação também foi verificada por Perez-Escamila e Haldeman (2002) em pesquisa com a população norte-americana.

O apelo de emagrecimento e saúde associados à DLG no meio virtual fez com que diferentes públicos se mobilizassem a aderir esta dieta, não apenas aqueles que são obrigados por motivos de saúde. Uma alegação em rótulo ("não contém glúten") que dantes não tinha significado para quase ninguém, atualmente é uma das formas mais persuasivas utilizadas pela indústria alimentícia para induzir o consumidor na hora das compras. Embora a conclusão de Dunn et al. (2014) ser de que apenas a informação no rótulo não afeta significativamente a percepção dos consumidores, estes afirmam crenças não fundamentadas a respeito do impacto positivo da DLG na saúde.

Mais de 50\% dos participantes do atual estudo também acreditam que para um emagrecimento efetivo, a dieta sem glúten é a mais indicada. Uma descoberta interessante foi feita no estudo de Perrin et al. (2019), que após observar o número de pessoas que evitam o glúten crescendo em muitos países ocidentais, realizou uma pesquisa de padrões alimentares de indivíduos que seguem uma DLG com a coorte francesa NutriNet-Santé, 
excluindo indivíduos celíacos, e percebeu maior ingestão de frutas, legumes e menor consumo de produtos lácteos, salgados, doces, alimentos gordurosos e álcool por estes indivíduos. Logo, o que tornava estes indivíduos mais saudáveis não era o simples fato de seguir uma dieta excluindo alimentos com glúten, mas sim, por incluir alimentos mais saudáveis e reduzir o consumo de produtos com elevada densidade energética, bem como diminuir a ingestão de bebidas alcóolicas.

Outro aspecto relevante é o marketing nutricional virtual dos PSG, que favorece a adoção, pelas empresas, de estratégias de concorrência que induzem o consumo de produtos sem glúten por um público que não depende desse tipo de alimento. Isto gera um aumento voluptuoso na demanda, e incentiva a elevação dos preços. Tal questão, apesar de não influenciar a escolha daqueles que querem ter um estilo de vida sem o glúten, prejudica os que de fato necessitam de PSG. Sarkhy et al. (2016) identificaram que mais de $60 \%$ das famílias sauditas com celíacos sofrem um forte impacto negativo socioeconômico da dieta sem glúten no orçamento familiar, sendo um dos principais fatores limitantes da adesão à dieta para os que de fato necessitam permanentemente da mesma (STEVENS; RASHID, 2008; SINGH; WHELAN, 2011).

O marketing nutricional virtual é veiculado pela internet $e$ em redes sociais, fontes principais relatadas pelos participantes da presente pesquisa para obtenção de informações a respeito dos alimentos sem glúten e sua associação com a perda de peso e ganho de qualidade de vida. Este comportamento pode ser relacionado ao conceito de normas sociais, definido por Herman e Higgs (2015) como sendo códigos de conduta que permeiam as relações levando ao fato do comportamento de um indivíduo ser baseado no comportamento do outro.

O estímulo de comportamentos alimentares transmitidos pelas mídias sociais atuais (Instagram, Facebook e Twitter) para atingir um determinado corpo e estilo de vida, estampados em publicações e em imagens, contribui para o aumento de pessoas cada vez mais preocupadas com o número de calorias ingeridas e a escolha do tipo de alimentos (HOLLAND; TIGGEMANN, 2016).

Este apelo virtual conforta o público, induzindo-o a acreditar que tudo o que está descrito no rótulo tem por objetivo informar e mostrar o cuidado com a saúde que o fabricante associa aos seus produtos, como evidenciado pelo relato de um participante que afirmou respirar aliviado quando adquire um alimento sem glúten, por ser “...um 
produto com menos malefícios e calorias, sendo assim mais saudável...”. Tal escolha alimentar se dá por fatores como emoções e humor, os quais são determinantes implícitos e indiretos na formação do comportamento alimentar, mediados pelos fatores ambientais, que são influenciadores importantes da intenção-comportamento (FISHBEIN, 2008; FISHBEIN; AJZEN, 2010).

Em contrapartida, há aqueles que acreditam que a alegação é uma estratégia de marketing do fabricante para "fingir" ser um alimento saudável, "mas na verdade só é um alimento que não tem farinha branca, é mais seco e esfarelento, e não contém trigo, centeio e etc".

Evitar o uso de informação enganosa na era digital é uma ação de alta complexidade, todavia a legislação que define as exigências de rotulagem deveria ser mais objetiva, a fim de promover um entendimento mais fácil e claro, sem dar margem para argumentos apenas persuasivos. No caso da LF 10.674/2003, não existe o formato e nem onde deve estar alocada a alegação sobre a presença de glúten. Esta informação deveria ficar em local neutro e adequado, como após a lista de ingredientes em caracteres nítidos. Essa sugestão não é inédita, pois consta na RDC 26/2015 que dispõe sobre os dizeres para alergênicos "Art. $8^{\circ}$ As advertências exigidas nos artigos $6^{\circ}$ e $7^{\circ}$ desta Resolução devem estar agrupadas imediatamente após ou abaixo da lista de ingredientes e com caracteres legíveis que atendam aos seguintes requisitos de declaração: I - caixa alta; II - negrito; III - cor contrastante com o fundo do rótulo; e IV - altura mínima de 2 mm e nunca inferior à altura de letra utilizada na lista de ingredientes". Um outro aspecto negativo contido na LF 10.674/2003 refere-se aos termos "evitar" e "medida preventiva", que podem levar o consumidor a acreditar que os alimentos sem glúten não devem ser consumidos para evitar complicações de saúde.

Outra circunstância que merece uma ação reguladora é a difusão de informações não fundamentadas aos consumidores por intermédio de mídias virtuais. Regras como aquelas exigidas na literatura científica, como a apresentação de referências, talvez pudessem restringir afirmações equivocadas e recomendações enganosas como a crença de que PSG são promotores da perda de peso, de saúde e de qualidade de vida como relatado por vários dos participantes do presente estudo.

Nesse contexto, ressalta-se ainda a importância da ação orientadora e fiscalizatória do Conselho Federal de Nutricionistas e da Federação Nacional das 
Associações de Celíacos do Brasil, bem como da ANVISA - Agência Nacional de Vigilância Sanitária, não apenas promovendo informação correta, mas também salientando a necessidade do acompanhamento de um profissional de saúde em qualquer tipo de restrição alimentar. 


\section{CONCLUSÕES}

O presente estudo constatou que a rotulagem de PSGs industrializados obedece a legislação no que diz respeito a informar o consumidor sobre a existência ou ausência de glúten em sua composição. Isto, contudo não impede a indústria de adaptar essa exigência para transformá-la em uma estratégia de marketing nutricional.

Tal fato se confirmou, por meio da análise da percepção de consumidores acerca dos PSG, quando se constatou crenças equivocadas e informações incorretas orientando o comportamento de consumidores leigos que seguiam e que não seguiam uma DLG.

Adicionalmente, observou-se que alimentos que não contém glúten possuem alta densidade energética e de sódio em todas as categorias analisadas. Na categoria das bolachas, ainda houve um elevado percentual de ácidos graxos saturados. O preço destes produtos é extremamente elevado, variando de 2 a 16 vezes mais do que os produtos tradicionais.

Mais de 50\% dos participantes analisados seguem uma dieta livre de glúten principalmente por acreditarem que são alimentos que promovem qualidade de vida e saúde, além de auxiliarem no emagrecimento.

A busca por informações a respeito da dieta livre de glúten geralmente é realizada na internet e em redes sociais, o que demonstra um envolvimento do que foi aqui denominado marketing nutricional virtual de PSGs, o qual incentiva a restrição do glúten para atingir objetivos não necessariamente comprovados cientificamente.

Conclui-se então que há necessidade de conscientização dos indivíduos por meio dos mesmos canais midiáticos onde são abordadas as informações enganosas, além de um aprimoramento da legislação vigente a respeito do glúten, a fim de padronizar o modo como a alegação a respeito do glúten está sendo veiculada nos rótulos. Para tanto, os resultados desta pesquisa serão divulgados junto Agência Nacional de Vigilância Sanitária, Conselho Federal de Nutricionistas, Conselho Regional de Nutricionistas e Federação Nacional das Associações de Celíacos do Brasil.

Se a percepção dos consumidores mudar em relação a esses produtos, e a demanda sem fundamento e necessidade reduzirem, o valor agregado destes produtos poderá 
diminuir, favorecendo o acesso para aqueles que de fato precisam comprar este tipo de alimento por toda a vida.

\section{SUGESTÕES PARA TRABALHOS FUTUROS}

Para trabalhos futuros seria interessante realizar a caracterização do padrão e comportamento alimentar de indivíduos não celíacos que seguem a dieta sem glúten no Brasil, para avaliar se eles fazem escolhas alimentares melhores. E é necessário realizar uma pesquisa de preço e acessibilidade dos produtos sem glúten no Brasil.

\section{FINANCIAMENTO}

O presente trabalho foi realizado com o apoio da Coordenação de Aperfeiçoamento de Pessoal de Nível Superior - Brasil (CAPES) - Código de Financiamento 001, com a concessão de uma bolsa de mestrado à discente.

\section{DECLARAÇÃO DE CONFLITO DE INTERESSES}

Declaro que não houve nenhum conflito de interesse neste trabalho. 


\section{REFERÊNCIAS}

AGUIAR A.; UEZIMA, C.; BRESSAM, J.; ZEMDEGS, J.; KRINAS, K.; GONÇALVES, M. et al. Manual de Nutrição: Profissional da Saúde. Departamento de Nutrição e Metabologia da SBD. São Paulo, 2009.

ALLEN, B.; ORFILA, C. The Availability and Nutritional Adequacy of Gluten-Free Bread and Pasta. Nutrients, 10, 1370, 2018.

ARENDT, E. K.; DAL BELLO, F. (Eds). Gluten-free cereal products and beverages. Estados Unidos, Elsevier, 2008. p. 393-411.

AZIZ, I.; BRANCHI, F.; SANDERS, D. The rise and fall of gluten! Proceedings of the Nutrition Society, v.74, p. 221-226, 2015.

BARLOW, J.; MAUL, D. Emotional Value: creating strong bonds with your costumers. 1. ed. San Francisco: Berrett-Koehler Publishers, 2000.

BLACKETT, J. W. et al. Characteristics and comorbidities of inpatients without celiac disease on a gluten-free diet. European Journal of Gastroenterology \& Hepatology, p. 1, 2018.

BOGUE, J.; SORENSON, D. The marketing of gluten-free cereal products. In: ARENDT, E. K.; DAL BELLO, F. (Eds). Gluten-free cereal products and beverages. Estados Unidos, Elsevier, 2008. p. 393-411.

BRASIL. LEI n 8.078. CDC - Código de Defesa do Consumidor. Brasília, DF, 1990.

BRASIL. LEI FEDERAL No 8.543. Determina a impressão de advertência em rótulos e embalagens de alimentos industrializados que contenham glúten, a fim de evitar a doença celíaca ou síndrome celíaca. Brasília, DF, 1992.

BRASIL. LEI FEDERAL $\mathrm{N}^{\mathrm{o}} 10.674$ Obriga a que os produtos alimentícios comercializados informem sobre a presença de glúten, como medida preventiva e de controle da doença celíaca. Brasília, DF, 2003.

BRASIL. Agência Nacional de Vigilância Sanitária. RESOLUÇÃO - RDC no 259. Discorre sobre rotulagem de alimentos embalados. Brasília, DF, 2002.

BRASIL. Agência Nacional de Vigilância Sanitária. RESOLUÇÃO - RDC nº 24. Dispõe sobre a oferta, propaganda, publicidade, informação e outras práticas correlatas cujo objetivo seja a divulgação e a promoção comercial de alimentos considerados com quantidades elevadas de açúcar, de gordura saturada, de gordura trans, de sódio, e de bebidas com baixo teor nutricional, nos termos desta Resolução, e dá outras providências, 2010 .

BROUNS, F. J. P. H.; VAN BUUL, V. J.; SHEWRY, P. R. Does wheat make us fat and sick? Journal of Cereal Science, v. 58, n. 2, p. 209-215, 2013. 
BRUICE, P. Y. Química Orgânica. 4a . Ed., Vol. 2. Pearson Prentice Hall, cap. 25, pg. 449, 2006.

CABRERA-CHÁVEZ F, DEZAR GV, ISLAS-ZAMORANO AP, et al. Prevalence of self-reported gluten sensitivity and adherence to a gluten-free diet in argentinian adult. Population. Nutrients 9, 81, 2017.

CABRERA-CHÁVEZ F, GRANDA-RESTREPO DM, ARÁMBURO-GÁLVEZ JG, ET AL. Self-reported prevalence of gluten-related disorders and adherence to gluten-free diet in Colombian adult population. Gastroenterol Res Pract 4704309, 2016.

CATASSI, C. et al. Non-celiac gluten sensitivity: The new frontier of gluten related disorders. Nutrients, v. 5, n. 10, p. 3839-3853, 2013.

CATASSI, C.; GATTI, S.; FASANO, A. The new epidemiology of celiac disease. Journal of Pediatric Gastroenterology and Nutrition, v. 59, n. SUPPL. 1, p. 7-9, 2014.

CATASSI, C; FASANO, A. Celiac Disease. In: ARENDT, E. K.; DAL BELLO, F. (Eds). Gluten-free cereal products and beverages. Estados Unidos, Elsevier, 2008. p. 1-22. COBRA, M. Administração de marketing no Brasil. 3.ed. Rio de Janeiro Elsevier, 2009. 456p.

Conselho da Justiça Federal, 2015. Disponível em: <https://www.cjf.jus.br/cjf/outrasnoticias/2013/fevereiro/anvisa-nao-tem-competencia-para-regulamentar-propaganda-epublicidade-comercial>. Acesso em: 27 jul 2019.

CRUCHET, S.; LUCERO, Y.; CORNEJO, V. Truths, Myths and Needs of Special Diets: Attention-Deficit/Hyperactivity Disorder, Autism, Non-Celiac Gluten Sensitivity, and Vegetarianism. Annals of Nutrition and Metabolism, v. 68, n. 1, p. 43-50, 2016.

CYRILLO, D.C. Reconstruindo instituições: o caso da Norma Brasileira para Comercialização de Alimentos para Lactentes (NBCAL). 2001. 167p. Tese de Livre Docência - Faculdade de Economia, Administração e Contabilidade - Universidade de São Paulo, São Paulo. 2001.

DUNN, C., HOUSE, L., \& SHELNUTT, K. P. CONSUMER PERCEPTIONS OF GLUTEN-FREE PRODUCTS AND THE HEALTHFULNESS OF GLUTEN-FREE DIETS. Journal of Nutrition Education and Behavior, 46(4), S184-S185, 2014. doi:10.1016/j.jneb.2014.04.280

ELLI, L. et al. Diagnosis of gluten related disorders: Celiac disease, wheat allergy and non-celiac gluten sensitivity. World Journal of Gastroenterology, v. 21, n. 23, p. 71107119, 2015.

FAO/WHO. CODEX ALIMENTARIUS INTERNATIONAL FOOD STANDARTS. Standard for foods for special dietary use for persons intolerant to gluten. CODEX STAN 118-1979. Adopted in 1979. Amendment: 1983 and 2015. Revision: 2008.

FASANO, A.; CATASSI, C. Celiac Disease. New England Journal of Medicine, v. 367, n. 25, p. 2419-2426, 2012. 
FISHBEIN, M. A reasoned action approach to health promotion. Med Decis Making, v. 28, n. 6, p. 834-844, 2008.FISHBEIN, M.; AJZEN, I. Predicting and Changing Behavior: The Reasoned Action Approach. New York: Psychology Press, 2010.

FOSCHIA, M. et al. Nutritional therapy - Facing the gap between coeliac disease and gluten-free food. International Journal of Food Microbiology, v. 239, p. 113-124, 2016.

FURQUIM, N. R. Alimento seguro: uma análise do ambiente institucional para oferta de carne bovina no Brasil. 2012. 152f. Tese (Doutorado) - Faculdade de Ciências Farmacêuticas da USP. Faculdade de Economia, Administração e Contabilidade da USP. Faculdade de Saúde Pública da USP, São Paulo. 2012.

GAESSER, G. A.; ANGADI, S. S. Navigating the gluten-free boom. Journal of the American Academy of Physician Assistants, v. 28, n. 8, p. 1-7, 2015.

GOMES, A.L.C.; CYRILLO, D.C. Utilização da rotulagem de alimentos embalados e a qualidade da alimentação de mulheres de uma região da cidade de São Paulo. Nutrire, v. 31, n. 1, p. 33-42, abr. 2006.

GONSALVES, M.I.E. Marketing Nutricional em rotulagem de iogurtes: uma avaliação crítica. 1997. 86f. Dissertação (Mestrado) - Faculdade de Ciências Farmacêuticas da USP. Faculdade de Economia, Administração e Contabilidade da USP. Faculdade de Saúde Pública da USP, São Paulo. 1997.

GRECO L. From the neolithic revolution to gluten intolerance: benefits and problems associated with the cultivation of wheat. J Pediatr Gastroenterol Nutr 24(5):S14-S16 (discussion S16-17), 1997.

GUANDALINI, S.; ASSIRI, A. Celiac Disease. JAMA Pediatrics, v. 168, n. 3, p. 272, 2014.

GULINI, J.E.H.M.B. et al. A equipe da Unidade de Terapia Intensiva frente ao cuidado paliativo: discurso do sujeito coletivo. Rev Esc Enferm USP, 2017.

HOLLAND, G., \& TIGGEMANN, M. (2016). A systematic review of the impact of the use of social networking sites on body image and disordered eating outcomes. Body Image, 17, 100-110, 2016). doi:10.1016/j.bodyim.2016.02.008

ISHIMOTO, E. Y.; NACIF, M. A. L. Propaganda e marketing na informação nutricional. Brasil Alimentos, ano II, n. 11, p. 28-33, 2001.

JODELET, D. Representações sociais: um domínio em expansão. Rio de janeiro: Eduerj; 2001. P. 17-44.

KABBANI TA, GOLDBERG A, KELLY CP, PALLAV K, TARIQ S, PEER A, HANSEN J, DENNIS M, LEFFLER D. Body mass index and the risk of obesity in coeliac disease treated with the gluten-free diet. Aliment Pharmacol Ther 35(6):723-729, 2012. doi:10.1111/j.1365-2036.2012.05001.x 
KASARDA, D. D. Can an increase in celiac disease be attributed to an increase in the gluten content of wheat as a consequence of wheat breeding? Journal of Agricultural and Food Chemistry, v. 61, n. 6, p. 1155-1159, 2013.

KOTLER, P. Administração de marketing. 10ed. São Paulo: Prentice Hall, 2000.

KOTLER, P.; KELLER, K.L. Administração de marketing. 12.ed. São Paulo: Pearson Prentice Hall, 2006. 750p.

LAMACCHIA, C. et al. Cereal-based gluten-free food: How to reconcile nutritional and technological properties of wheat proteins with safety for celiac disease patients. Nutrients, v. 6, n. 2, p. 575-590, 2014.

LEFEVRE F., LEFEVRE AMC, TEIXEIRA JJV e organizadores. O discurso do sujeito coletivo: uma nova abordagem metodológica em pesquisa qualitativa. Caxias do sul: Educs; 2000.

LEFEVRE, F.; LEFEVRE, A. M. C. Discurso do Sujeito Coletivo: Representações sociais e intervenções comunicativas. Texto e Contexto Enfermagem, v. 23, n. 2, p. 502-507, 2014.

LEFEVRE, F.; LEFEVRE, A. M. C. O sujeito coletivo que fala. Interface Comunicação, Saúde, Educação, v. 10, n. 20, p. 517-524, 2006.

LUDVIGSSON, J. F. et al. The Oslo definitions for coeliac disease and related terms. Gut, v. 62, n. 1, p. 43-52, 2013.

MACHADO, F. M. S. Estratégias de concorrência da indústria alimentícia e seus desdobramentos na dimensão nutricional. 2003. 200f. Tese (Doutorado) - Faculdade de Ciências Farmacêuticas da USP. Faculdade de Economia, Administração e Contabilidade da USP. Faculdade de Saúde Pública da USP, São Paulo. 2003.

MACIEL, E. O gostoso e o saudável: uma análise da utilização de apelos de saúde na rotulagem de alimentos e sua convergência com o conteúdo nutricional. 2012. 148f. Dissertação (Mestrado) - Faculdade de Ciências Farmacêuticas da USP. Faculdade de Economia, Administração e Contabilidade da USP. Faculdade de Saúde Pública da USP, São Paulo. 2012.

MARIANI P, VITI MG, MONTUORI M, LA VECCHIA A, CIPOLLETTA E, CALVANI L, BONAMICO M. The gluten-free diet: a nutritional risk factor for adolescents with celiac disease? J Pediatr Gastroenterol Nutr 27(5):519-523, 1998.

MARTIN J, GEISEL T, MARESCH C, et al. Inadequate nutrient intake in patients with celiac disease: results from a German dietary survey. Digestion 2013;87(4):240-6.

MISSBACH, B., SCHWINGSHACKL, L., BILLMANN, A., MYSTEK, A., Hickelsberger, M., Bauer, G., \& König, J. Gluten-free food database: the nutritional 
quality and cost of packaged gluten-free foods. PeerJ, 3, e1337, 2015. doi:10.7717/peerj.1337.

MOCAN, O.; DUMITRAȘCU, D. L. The Broad Spectrum of Celiac Disease and Gluten Sensitive Enteropathy. Clujul Medical, v. 89, n. 3, p. 335, 2016.

MOORE, L. R. "But we're not hypochondriacs": The changing shape of gluten-free dieting and the contested illness experience. Social Science and Medicine, v. 105, p. 7683, 2014.

NORSA L, SHAMIR R, ZEVIT N, VERDUCI E, HARTMAN C, GHISLENI D, RIVA E, GIOVANNINI M. Cardiovascular disease risk fator profiles in children with celiac disease on gluten-free diets. World J Gastroenterol 19(34):5658-5664, 2013. doi:10.3748/wjg.v19.i34.5658.

OHLUND K, OLSSON C, HERNELL O, OHLUND I. Dietary shortcomings in children on a gluten-free diet. J Hum Nutr Diet ;23(3):294-300, 2010.

OJETTI, V.; NUCERA, G.; MIGNECO, A.; GABRIELLI, M.; LAURITANO, C.; DANESE, S.; ASSUNTA ZOCCO, M.A.; NISTA, E.C.; CAMMAROTA, G.; DE LORENZO, A.; et al. High prevalence of celiac disease in patients with lactose intolerance. Digestion, 71, 106-110, 2005.

ONTIVEROS, N., RODRÍGUEZ-BELLEGARRIGUE, C., GALICIA-RODRÍGUEZ, G., VERGARA-JIMÉNEZ, M., ZEPEDA-GÓMEZ, E., ARÁMBURO-GALVEZ, J., ... CABRERA-CHÁVEZ, F. (2018). Prevalence of Self-Reported Gluten-Related Disorders and Adherence to a Gluten-Free Diet in Salvadoran Adult Population. International Journal of Environmental Research and Public Health, 15(4), 786, 2018. doi:10.3390/ijerph15040786.

PANAGIOTOU, S.; KONTOGIANNI, M. D. The economic burden of gluten-free products and gluten-free diet : a cost estimation analysis in Greece. Journal of Human Nutrition and Dietetics, p. 1-7, 2017.

PEREZ-ESCAMILA, R.; HALDEMAN, L. Food Label use modifies association of income with dietary quality. Journal Nutrition, v. 132, n. 2, p. 768-772, 2002.

PSZCZOLA, D.E. The rise of gluten-free. Food Technology, v. 66, n. 12, p. 55-66, 2012. REILLY, N. R. The Gluten-Free Diet: Recognizing Fact, Fiction, and Fad. Journal of Pediatrics, v. 175, p. 206-210, 2016.

RIVERA, E.; ASSIRI, A.; GUANDALINI, S. Celiac disease. Oral Diseases, v. 19, n. 7, p. 635-641, 2013.

RODRIGUES, R. M. A. Marketing: uma abordagem nutricional. 2010. 54f. Monografia (Licenciatura em ciências da nutrição) - Faculdade de Ciências da Nutrição e Alimentação da Universidade do Porto, Porto. 2010.

ROLLS, B. et al. Energy density but not fat content of foods affected energy intake, Am J Clin Nutr:863-71, 1999;69, 1999. 
ROSELL, C. M. et al. Cereals for developing gluten-free products and analytical tools for gluten detection. Journal of Cereal Science, v. 59, n. 3, p. 354-364, 2014.

ROSTAMI, K. et al. Gluten-free diet indications, safety, quality, labels, and challenges. Nutrients, v. 9, n. 8, p. 10-14, 2017.

RYBICKA, I. The Handbook of Minerals on a Gluten-Free Diet. Nutrients, 10, 1683, 2018.

SARKHY, A., EL MOUZAN, M. I., SAEED, E., ALANAZI, A., ALGHAMDI, S., ANIL, S., \& ASSIRI, A. (2016). Socioeconomic Impacts of Gluten-Free Diet among Saudi Children with Celiac Disease. Pediatric Gastroenterology, Hepatology \& Nutrition, 19(3), 162, 2016. doi:10.5223/pghn.2016.19.3.162.

SCHERER, F. M. Industrial market structure and economic performance. 2ed. Chicago: Raud McNally e Co, 1970.

SCHERER, F. M.; ROSS, D. Industrial market structure and economic performance. 3ed. Chicago: Raud McNally e Co, 1990.

SEE, J. A. et al. Practical insights into gluten-free diets. Nature Reviews Gastroenterology and Hepatology, v. 12, n. 10, p. 580-591, 2015.

SHAN L, MOLBERG O, PARROT I, et al. Structural basis for gluten intolerance in celiac sprue. Science; 297: 2275-79, 2002.

SILVA, T. S. G.; FURLANETTO, T. W. Diagnóstico da doença celíaca em adultos. Revista da Associação Médica Brasileira, v. 56, n. 1, p. 122-6, 2010.

SILVESTER, J. A. et al. Living gluten-free: Adherence, knowledge, lifestyle adaptations and feelings towards a gluten-free diet. Journal of Human Nutrition and Dietetics, v. 29, n. 3, p. 374-382, 2016.

Sin gluten en las etiquetas: ¿Información para los celíacos o técnica de marketing? Disponível em <https://murciaeconomia.com/art/62980/sin-gluten-en-las-etiquetasinformacion-para-los-celiacos-o-tecnica-de-marketing> Acesso em: 8 jul 2019.

SINGH, P. et al. Global Prevalence of Celiac Disease: Systematic Review and Metaanalysis. Clinical Gastroenterology and Hepatology, 2018.

SKODJE, G. I. et al. Fructan, Rather Than Gluten, Induces Symptoms in Patients With Self-reported Non-celiac Gluten Sensitivity. Gastroenterology, v. 154, n. 3, p. 529539.e2, 2017.

SONTAG-STROHM, T.; LEHTINEN, P. KAUKOVIRTA-NORJA, A. Oat products and their current status in the celiac diet. In: ARENDT, E. K.; DAL BELLO, F. (Eds). Glutenfree cereal products and beverages. Estados Unidos, Elsevier, p. 191-199, 2008. 
STEVENS L, RASHID M. Gluten-free and regular foods: a cost comparison. Can J Diet Pract Res; 69:147-50, 2008.

STRINGHETA, P. C. et al. Políticas de saúde e alegações de propriedades funcionais e de saúde para alimentos no Brasil. Revista Brasileira de Ciências Farmacêuticas, v. 43, n. 2, p. 181-194, 2007.

STROM, S. (2014). A big bet on gluten-free. The New York Times, fev/2014. Disponível em: $\quad$ https://www.nytimes.com/2014/02/18/business/food-industry-wagers-big-ongluten-free.html?.r\%C2\%BC2>. Acesso em: 28 jun 2017.

ROLLS B. et al. Energy density but not fat content of foods affected energy intake. Am J Clin Nutr, 69:863-71, 1999.

TOPPER, A (2014). Non-celiacs drive gluten-free market growth. Mintel. Disponível em: <http://www.mintel.com/blog/food-market-news/gluten-free-consumption- trends>. Acesso em: 02 AGO 2019.

THEETHIRA T.G., DENNIS M. (2015) Celiac disease and the glutenfree diet: consequences and recommendations for improvement. Dig Dis 33(2):175-182, 2015. doi:10.1159/000369504

THEETHIRA, T. G., DENNIS, M., \& LEFFLER, D. A. (2014). Nutritional consequences of celiac disease and the gluten-free diet. Expert Review of Gastroenterology \& Hepatology, 8(2), 123-129.doi:10.1586/17474124.2014.876360

TORTORA, R.; CAPONE, P.; DE STEFANO, G.; IMPERATORE, N.; GERBINO, N.; DONETTO, S.; MONACO, V.; CAPOORASO, N.;RISPO, A. Metabolic syndrome in patients with coeliac disease on a gluten-free diet. Aliment. Pharmacol. Ther., 41, 352$359,2005$.

VARIAN, H. N. Microeconomia: princípios básicos. 5ed. Rio de Janeiro: Campus, 2000.

VINCHA, K. R. R. et al. "Então não tenho como dimensionar": um retrato de grupos educativos em saúde na cidade de São Paulo, Brasil. Cadernos de Saúde Pública, v. 33, n. 9, 2017.

WATKINS, R. D.; ZAWAHIR, S. Celiac Disease and Nonceliac Gluten Sensitivity. Pediatric Clinics of North America, v. 64, n. 3, p. 563-576, 2017.

WEGMAN, J. et al. Top-down expectation effects of food labels on motivation. NeuroImage, v. 173, p. 13-24, 2018.

WIECH, P.; CHMIEL, Z.; BAZALINSKI, D.; SALACINSKA, I.; BARTOSIEWICZ, A.; MAZUR, A.; KORCZOWSKI, B.; BINKOWSKA-BURY, M.; DABROWSKI, M. The Relationship between Body Composition and a Gluten Free Diet in Children with Celiac Disease. Nutrients, 10, 1817, 2018. 
WIESER, H. Chemistry of gluten proteins. Food Microbiology, v. 24, n. 2, p. 115-119, 2007.

WIESER, H. Detection of gluten. In: ARENDT, E. K.; DAL BELLO, F. (Eds). Glutenfree cereal products and beverages. Estados Unidos, Elsevier, 2008. p. 47-72.

WILD D, ROBINS GG, BURLEY VJ, HOWDLE PD. Evidence of high sugar intake, and low fibre and mineral intake, in the gluten-free diet. Aliment Pharmacol Ther 32(4):573-581, 2010. doi:10.1111/j.1365-2036.2010.04386.x

WU, J.H.Y.; NEAL, B.; TREVENA, H.; CRINO, M.; STUART-SMITH, W.; FAULKNER-HOGG, K.; LOUIE, J.C.Y.; DUNFORD, E. Are gluten-free foods healthier than non-gluten-free foods? An evaluation of supermarket products in Australia. British Journal of Nutrition. 2015, 114: 448-454.

ZANNINI, E. et al. Functional Replacements for Gluten. Annual Review of Food Science and Technology, v. 3, n. 1, p. 227-245, 2012. 


\section{Anexo I - Parecer do Comitê de Ética em Pesquisa}

\section{PARECER CONSUBSTANCIADO DO CEP}

DADOS DO PROJETO DE PESQUISA

Título da Pesquisa: Impacto das alegações relativas ao glúten sobre as escolhas dos consumidores

Pesquisador: Denise C Cyrillo

Área Temática:

Versão: 2

CAAE: 80531317.1 .0000 .0067

Instituição Proponente: Faculdade de Ciências Farmacêuticas da Universidade de São Paulo

Patrocinador Principal: Financiamento Próprio

\section{DADOS DO PARECER}

\section{Número do Parecer: 2.542.919}

\section{Apresentação do Projeto:}

Os produtos sem glúten vêm aumentando sua participação no mercado atual, direcionados a uma população com restrição alimentar, como no caso da doença celíaca, sensibilidade ao glúten e alergia ao trigo. Para segurança destes consumidores, foram criadas legislações acerca das informações contidas nos rótulos, alegando a presença ou não de glúten nos produtos. No entanto, a alegação "NÃO CONTÉM GLÚTEN" pode estar sendo utilizada pela indústria como um elemento de sua estratégia de concorrência. Sendo assim, o objetivo dessa pesquisa é avaliar o impacto do marketing nutricional de alimentos industrializados sem glúten sobre as escolhas alimentares dos consumidores, por meio de uma pesquisa qualitativa descritiva utilizando o método do Discurso do Sujeito Coletivo DSC que possibilitará analisar a interpretação do consumidor acerca das informações dos rótulos; e verificar a conformidade das alegações nos rótulos dos produtos sem glúten à legislação. De acordo com os resultados obtidos, pretende-se propor aprimoramentos da legislação vigente.

\section{Objetivo da Pesquisa:}

Objetivo Primário:

Analisar a influência do marketing nutricional na rotulagem de produtos sem glúten por processamento, derivados do trigo, sobre as escolhas dos consumidores.

Endereço: Av. Prof. Lineu Prestes, 580, Bloco 13A, sala 112

Bairro: Butantã CEP: 05.508-000

UF: SP Município: SAO PAULO

Telefone: (11)3091-3622 Fax: (11)3031-8986 E-mail: cepfcf@usp.br 


\section{Objetivo Secundário:}

-Levantar o universo de produtos industrializados sem glúten por processamento, derivados do trigo;- Analisar a obediência da rotulagem destes produtos conforme as determinações da LF no 10.674/2003;- Investigar a interpretação dos consumidores acerca das alegações relativas ao glúten, contidas na rotulagem de produtos industrializados com e sem glúten, segundo condição de saúde (com ou sem doença celíaca) e a decisão de compra dada a alegação;-Propor aprimoramentos da legislação vigente.

\section{Avaliação dos Riscos e Benefícios:}

Riscos:

A pesquisa impõe risco mínimo aos participantes, pois se trata de uma abordagem não invasiva, realizada por meio de questionários digitais, com questões referentes a percepção e consumo de produtos sem glúten, a dados socioeconômicos e demográficos. Caso o participante se sinta constrangido para responder alguma das questões, poderá desistir e tirar seu consentimento a qualquer momento, sem nenhum prejuízo. Benefícios:

Ao enviar as respostas do questionário, o participante receberá, automaticamente, um folder contendo informações sobre as doenças relacionadas ao trigo e sobre os produtos sem glúten, como benefício de sua participação na pesquisa. Os resultados obtidos serão utilizados para fins acadêmicos, sem a identificação do participante, e o mesmo receberá informações sobre a pesquisa a qualquer momento, a título de conhecimento e conscientização a respeito do papel dos produtos sem glúten no mercado.

\section{Comentários e Considerações sobre a Pesquisa:}

A pesquisa é interessante pois visa conhecer o comportamento do consumidor frente à informação constante nos rótulos de produtos alimentícios sobre o conteúdo ou não de glúten; qual a leitura que o consumidor faz dessa informação.

\section{Considerações sobre os Termos de apresentação obrigatória:}

O proponente realizou as correções e ajustes indicados. O TCLE foi reformulado em linguagem simples e foram esclarecidos riscos, benefícios, condições de sigilo de dados e os telefones e emails para esclarecimento de dúvidas.

Endereço: Av. Prof. Lineu Prestes, 580, Bloco 13A, sala 112

Bairro: Butantã CEP: 05.508-000

UF: SP Município: SAO PAULO

Telefone: (11)3091-3622 Fax: (11)3031-8986Ｅ-mail: cepfcf@usp.br 


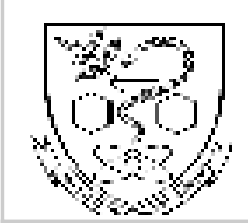

Continuação do Parecer: 2.542 .919

\section{Recomendações:}

Sem recomendações e pendências.

Conclusões ou Pendências e Lista de Inadequações:

Este CEP considera o projeto adequado e aprovado.

\section{Considerações Finais a critério do CEP:}

O projeto segue as exigências da legislação.

Este parecer foi elaborado baseado nos documentos abaixo relacionados:

\begin{tabular}{|c|c|c|c|c|}
\hline Tipo Documento & Arquivo & Postagem & Autor & Situação \\
\hline $\begin{array}{l}\text { Informações Básicas } \\
\text { do Projeto }\end{array}$ & $\begin{array}{l}\text { PB_INFORMAÇOES_BASICAS_DO_P } \\
\text { ROJETO_1036139.pdf }\end{array}$ & $\begin{array}{l}09 / 03 / 2018 \\
14: 43: 27\end{array}$ & & Aceito \\
\hline Outros & CartaRespostaCEP.pdf & $\begin{array}{l}09 / 03 / 2018 \\
14: 41: 03\end{array}$ & $\begin{array}{l}\text { TAINA FERNANDES } \\
\text { DRUB }\end{array}$ & Aceito \\
\hline $\begin{array}{l}\text { Projeto Detalhado / } \\
\text { Brochura } \\
\text { Investigador }\end{array}$ & $\begin{array}{l}\text { ProjetoMestradoCEPoficial_TainaDrub.p } \\
\text { df }\end{array}$ & $\begin{array}{c}09 / 03 / 2018 \\
14: 39: 53\end{array}$ & $\begin{array}{l}\text { TAINA FERNANDES } \\
\text { DRUB }\end{array}$ & Aceito \\
\hline $\begin{array}{l}\text { TCLE / Termos de } \\
\text { Assentimento / } \\
\text { Justificativa de } \\
\text { Ausência }\end{array}$ & TCLE_TainaDrub.pdf & $\begin{array}{c}\text { 09/03/2018 } \\
14: 39: 28\end{array}$ & $\begin{array}{l}\text { TAINA FERNANDES } \\
\text { DRUB }\end{array}$ & Aceito \\
\hline Cronograma & CronogramaAnosMeses_TainaDrub.pdf & $\begin{array}{c}09 / 03 / 2018 \\
14: 39: 10\end{array}$ & $\begin{array}{l}\text { TAINA FERNANDES } \\
\text { DRUB }\end{array}$ & Aceito \\
\hline Outros & $\begin{array}{l}\text { DeclaracaoDispensaAnuenciaFCF_Tain } \\
\text { aDrub.pdf }\end{array}$ & $\begin{array}{c}29 / 11 / 2017 \\
14: 26: 29\end{array}$ & $\begin{array}{l}\text { TAINA FERNANDES } \\
\text { DRUB }\end{array}$ & Aceito \\
\hline Outros & ParticipantesdoProjeto_TainaDrub.pdf & $\begin{array}{l}\text { 29/11/2017 } \\
14: 25: 05\end{array}$ & $\begin{array}{l}\text { TAINA FERNANDES } \\
\text { DRUB }\end{array}$ & Aceito \\
\hline $\begin{array}{l}\text { Declaração de } \\
\text { Pesquisadores }\end{array}$ & $\begin{array}{l}\text { DeclaracaodeParticipacao_TainaDrub.p } \\
\text { df }\end{array}$ & $\begin{array}{l}\text { 29/11/2017 } \\
14: 23: 51\end{array}$ & $\begin{array}{l}\text { TAINA FERNANDES } \\
\text { DRUB }\end{array}$ & Aceito \\
\hline $\begin{array}{l}\text { Declaração de } \\
\text { Pesquisadores }\end{array}$ & $\begin{array}{l}\text { DeclaracaodeParticipacao_ProfaDenise. } \\
\text { pdf }\end{array}$ & $\begin{array}{l}\text { 29/11/2017 } \\
14: 23: 37\end{array}$ & $\begin{array}{l}\text { TAINA FERNANDES } \\
\text { DRUB }\end{array}$ & Aceito \\
\hline Folha de Rosto & PlataformaBrasilTainaDrub.pdf & $\begin{array}{c}27 / 11 / 2017 \\
22: 51: 28\end{array}$ & $\begin{array}{l}\text { TAINA FERNANDES } \\
\text { DRUB }\end{array}$ & Aceito \\
\hline
\end{tabular}

\section{Situação do Parecer: \\ Aprovado \\ Necessita Apreciação da CONEP: \\ Não}

SÃO PAULO, 14 de Março de 2018

Assinado por:

Cristina Northfleet de Albuquerque (Coordenador)

Endereço: Av. Prof. Lineu Prestes, 580, Bloco 13A, sala 112

Bairro: Butantã CEP: 05.508-000

UF: SP Município: SAO PAULO

Telefone: (11)3091-3622 Fax:(11)3031-8986 E-mail: cepfcf@usp.br 
Anexo II - Características socioeconômicas e demográficas gerais dos grupos Segue e Não segue uma dieta livre de glúten - 2019

\begin{tabular}{|c|c|c|c|}
\hline CARACTERÍSTICAS & SEGUE & NÃO SEGUE & TOTAL \\
\hline \multicolumn{4}{|l|}{ MÉDIA DE IDADE (ANOS) } \\
\hline & 42,4 & 44,9 & 44,4 \\
\hline \multicolumn{4}{|l|}{ MÉDIA DE IMC (kg/m²) } \\
\hline & 24,5 & 26,3 & 25,2 \\
\hline \multicolumn{4}{|l|}{ SEXO (\%) } \\
\hline Sexo Feminino & 96,9 & 81,8 & 90,7 \\
\hline Sexo Masculino & 3,1 & 18,2 & 9,3 \\
\hline Total $(\%)$ & 100,0 & 100,0 & 100,0 \\
\hline \multicolumn{4}{|l|}{ COR (\%) } \\
\hline Amarelo & 9,4 & 18,2 & 13,0 \\
\hline Branco & 75,0 & 77,3 & 75,9 \\
\hline Pardo & 15,6 & 4,5 & 11,1 \\
\hline Total $(\%)$ & 100,0 & 100,0 & 100,0 \\
\hline \multicolumn{4}{|l|}{ ESCOLARIDADE (\%) } \\
\hline Fundamental Incompleto & 3,1 & 0,0 & 1,9 \\
\hline Fundamental Completo & 6,3 & 4,5 & 5,6 \\
\hline Médio Incompleto & 0,0 & 4,5 & 1,9 \\
\hline Médio Completo & 6,3 & 13,6 & 9,3 \\
\hline Superior Incompleto & 18,8 & 13,6 & 16,7 \\
\hline Superior Completo ou mais & 65,6 & 63,6 & 64,8 \\
\hline Total $(\%)$ & 100,0 & 100,0 & 100,0 \\
\hline \multicolumn{4}{|c|}{ REGIÃO DE ORIGEM NO BRASIL (\%) } \\
\hline Norte & 9,4 & 0,0 & 5,6 \\
\hline Sudeste & 62,5 & 95,5 & 75,9 \\
\hline Sul & 28,1 & 4,5 & 18,5 \\
\hline Total $(\%)$ & 100,0 & 100,0 & 100,0 \\
\hline \multicolumn{4}{|c|}{ PESSOAS NA MESMA RESIDÊNCIA (\%) } \\
\hline Até 3 pessoas & 65,6 & 59,1 & 63,0 \\
\hline De 3 a 4 pessoas & 18,8 & 36,4 & 25,9 \\
\hline De 4 a 5 pessoas & 9,4 & 4,5 & 7,4 \\
\hline 6 ou mais pessoas & 6,3 & 0,0 & 3,7 \\
\hline Total $(\%)$ & 100,0 & 100,0 & 100,0 \\
\hline \multicolumn{4}{|l|}{ RENDA INDIVIDUAL (\%) } \\
\hline Até R\$ 954,00 & 21,9 & 4,5 & 14,8 \\
\hline De R\$ 955,00 a R\$ 1908,00 & 12,5 & 9,1 & 11,1 \\
\hline De R\$ 1909,00 a R\$ 2862,00 & 15,6 & 22,7 & 18,5 \\
\hline De $\mathrm{R} \$ 2863,00$ a $\mathrm{R} \$ 4770,00$ & 21,9 & 18,2 & 20,4 \\
\hline De $\mathrm{R} \$ 4771,00$ a $\mathrm{R} \$ 9540,00$ & 12,5 & 22,7 & 16,7 \\
\hline Mais de $\mathrm{R} \$ 9540,00$ & 15,6 & 22,7 & 18,5 \\
\hline Total $(\%)$ & 100,0 & 100,0 & 100,0 \\
\hline \multicolumn{4}{|l|}{ RENDA FAMILIAR (\%) } \\
\hline Até R\$954,00 & 3,1 & 4,5 & 3,7 \\
\hline De R\$ 955,00 a R\$ 1908,00 & 15,6 & 4,5 & 11,1 \\
\hline De R\$ 1909,00 a $R \$ 2862,00$ & 18,8 & 4,5 & 13,0 \\
\hline De $\mathrm{R} \$ 2863,00$ a $\mathrm{R} \$ 4770,00$ & 12,5 & 13,6 & 13,0 \\
\hline De $\mathrm{R} \$ 4771,00$ a $\mathrm{R} \$ 9540,00$ & 21,9 & 27,3 & 24,1 \\
\hline Mais de $\mathrm{R} \$ 9540,00$ & 28,1 & 45,5 & 35,2 \\
\hline Total $(\%)$ & 100,0 & 100,0 & 100,0 \\
\hline
\end{tabular}


Apêndice I - Termo de Consentimento Livre e Esclarecido

UNIVERSIDADE DE SÃO PAULO

FACULDADE DE CIÊNCIAS FARMACÊUTICAS

PROGRAMA DE PÓS GRADUAÇÃO INTERUNIDADES EM NUTRIÇÃO

HUMANA APLICADA (PRONUT/USP)

TERMO DE CONSENTIMENTO LIVRE E ESCLARECIDO - TCLE

PARTICIPANTE DA PESQUISA

\section{Informações do Participante da Pesquisa}

\section{Nome:}

Email:

Idade:

Sexo: ( ) M ( ) F

( ) Outra Opção

Cor: ( ) Branco; ( ) Preto; ( ) Amarelo; ( ) Pardo; ( ) Indígena

\section{Título do Projeto de Pesquisa}

Impacto das alegações relativas ao glúten sobre as escolhas dos consumidores.

\section{Duração da Pesquisa}

30 meses

\section{Nome do Pesquisador Responsável}

Profa. Dra. Denise Cavallini Cyrillo 


\begin{tabular}{|l|l|}
\hline Cargo/ Função: Professora & $\mathrm{N}^{\circ}$ de registro do Conselho Regional: CORECON \\
associada da Universidade de São & $\mathrm{n}^{\circ} 08164$ \\
Paulo (USP) & \\
\hline
\end{tabular}

\section{Instituição}

Faculdade de Economia, Administração e Contabilidade da Universidade de São Paulo FEA/USP

\section{CONVITE}

Você está sendo convidado (a), como voluntário (a) para participar da pesquisa de mestrado intitulada "Impacto das alegações relativas ao glúten sobre as escolhas dos consumidores", cujo objetivo é analisar a influência do marketing nutricional dos produtos sem glúten sobre as escolhas dos consumidores.

Sua participação nesta pesquisa será respondendo a um questionário durante 15 a 20 minutos, por meio digital, com questões abertas e fechadas.

Não haverá qualquer tipo de despesa pessoal e constrangimento, nem previsão de indenização por danos. As informações coletadas serão tratadas com sigilo absoluto e não serão citadas em nível individual.

A pesquisa impõe risco mínimo aos participantes, pois se trata de uma abordagem não invasiva, realizada por meio de questionários digitais, com questões referentes a percepção e consumo de produtos sem glúten, a dados socioeconômicos e demográficos. Caso o participante se sinta constrangido para responder alguma das questões, poderá desistir e tirar seu consentimento a qualquer momento, sem nenhum prejuízo. Ao enviar as respostas do questionário, o participante receberá, automaticamente, um folder contendo informações sobre as doenças relacionadas ao trigo e sobre os produtos sem glúten, como benefício de sua participação na pesquisa. 
Os resultados obtidos serão utilizados para fins acadêmicos, sem a identificação do participante, e o mesmo receberá informações sobre a pesquisa a qualquer momento, a título de conhecimento e conscientização a respeito do papel dos produtos sem glúten no mercado.

Caso você concorde em participar desta pesquisa, assine ao final deste documento, o qual possui duas vias, sendo uma delas sua, e a outra, do pesquisador responsável. Os telefones e o endereço institucional do pesquisador responsável e do Comitê de Ética em Pesquisa - CEP, onde você poderá tirar suas dúvidas sobre o projeto e a sua participação nele, também estão ao final do documento.

Professora Responsável: Profa. Dra. Denise Cavallini Cyrillo (PRONUT - FEA/USP Contato: dccyrill@usp.br / (11) 3091-5898)

Pesquisadora Responsável: Mestranda Tainá Fernandes Drub (Nutricionista CRN51019/P, PRONUT - USP - Contato: tainadrub@ usp.br / (11) 3091-5898)

\section{Consentimento Pós-Esclarecido}

$\mathrm{Eu}$, declaro que, após ter sido convenientemente esclarecido pelo pesquisador e ter entendido o que me foi explicado, consinto em participar do presente Protocolo de Pesquisa.

São Paulo, de de

Para qualquer questão, dúvida, esclarecimento ou reclamação sobre aspectos éticos relativos a este protocolo de pesquisa, favor entrar em contato com o Comitê de Ética em Pesquisa da Faculdade de Ciências Farmacêuticas da Universidade de São Paulo: Av. Prof. Lineu Prestes, 580, Bloco 13 A, Butantã, São Paulo, CEP 05508-000, Telefones 3091-3622 e 3091-3677, e-mail: cepfcf@ usp.br. 
Apêndice II - Questionário Sobre a Percepção dos Consumidores em Relação ao Glúten

\section{TERMO DE CONSENTIMENTO LIVRE E ESCLARECIDO}

Esta pesquisa foi submetida e aprovada pelo Comitê de Ética em Pesquisa da Faculdade de Ciências Farmacêuticas - USP. POR GENTILEZA, NÃO BUSCAR OUTROS MEIOS DE CONHECIMENTO PARA RESPONDÊ-LO, POIS O OBJETIVO DA PESQUISA É ENTENDER SUAS PERCEPÇÕES ATÉ O MOMENTO. Caso você concorde em participar, assinale a resposta "SIM" e prossiga. Lembrando que a qualquer momento pode retirar o seu consentimento.

( ) SIM

( ) $\mathrm{NÃO}$

INFORMAÇÕES DO PARTICIPANTE

Nome completo / Endereço de email / Idade / Sexo / Cor

Qual é a sua escolaridade? (Fundamental Incompleto; Fundamental Completo; Médio Incompleto; Médio Completo; Superior Incompleto; Superior Completo ou mais).

\section{Qual a sua ocupação/profissão?}

Em qual região do Brasil você mora? NORTE (Tocantins, Acre, Pará, Rondônia, Roraima, Amapá e Amazonas); CENTRO-OESTE (Mato Grosso, Mato Grosso do Sul, Goiás e Distrito Federal); NORDESTE (Bahia, Sergipe, Alagoas, Paraíba, Pernambuco, Rio Grande do Norte, Ceará, Piauí e Maranhão); SUDESTE (Espírito Santo, Rio de Janeiro, Minas Gerais e São Paulo); SUL (Santa Catarina, Rio Grande do Sul e Paraná).

Quantas pessoas moram em sua residência (contando com você)? (Até 3 pessoas; De 3 a 4 pessoas; De 4 a 5 pessoas; 6 ou mais pessoas). 
Qual é a sua faixa de rendimento salarial INDIVIDUAL? (Até $\mathrm{R} \$ 954,00$; De $\mathrm{R} \$$ 955,00 a R \$ 1908,00; De R \$ 1909,00 a R\$2862,00; De R \$ 2863,00 a R \$ 4770,00; De $\mathrm{R} \$ 4771,00$ a R\$ 9540,00; Mais de R\$ 9540,00.

Qual é a sua faixa de rendimento salarial FAMILIAR (individual + pessoas que residem com você)? (Até $R$ \$ 954,00; De $R$ \$ 955,00 a $R$ \$ 1908,00; De R \$ 1909,00 a R\$ 2862,00; De R\$2863,00 a R\$4770,00; De R\$ 4771,00 a $\mathrm{R} \$$ 9540,00; Mais de $\mathrm{R} \$$ $9540,00)$.

Qual seu peso atual? (Exemplo: $60 \mathrm{~kg}$ )

Qual sua altura? (Exemplo: 1,60 m)

\section{SOBRE O GLÚTEN}

1) Você tem algum problema de saúde relacionado ao glúten? (SIM ou NÃO)

1.2) Se você respondeu SIM na questão 1, qual problema de saúde relacionado ao glúten você tem? Pode assinalar mais de uma alternativa. (Doença celíaca (Diagnóstico COM BIÓPSIA; Doença celíaca (diagnóstico com profissional da saúde SEM BIÓPSIA); Doença celíaca (autodiagnóstico); Sensibilidade ao glúten não celíaca (diagnóstico por profissional da saúde); Sensibilidade ao glúten não celíaca (autodiagnóstico); Alergia ao trigo (diagnótico por profissional da saúde); Outra doença intestinal que precisei realizar a exclusão do glúten (diagnóstico por profissional da saúde); Outra doença intestinal que precisei realizar a exclusão do glúten (autoindicação); Alergia inespecífica que precisei realizar a exclusão do glúten (diagnóstico por profissional da saúde); Alergia inespecífica que precisei realizar a exclusão do glúten (autoindicação); Doença psíquica (autismo, depressão, ansiedade e outros) que precisei realizar a exclusão do glúten (diagnóstico por profissional da saúde); Doença psíquica (autismo, depressão, ansiedade e outros) que precisei realizar a exclusão do glúten (autoindicação); Nenhuma das anteriores. 
1.3) Caso tenha assinalado "nenhuma das anteriores" na questão 1.2, por gentileza, especifique.

2) Em suas compras de alimentos, você costuma ler o rótulo dos produtos? (Sim, todas as vezes; Sim, às vezes; Sim, na primeira compra de cada produto novo; Não).

3) Você adquire um alimento quando identifica que ele CONTÉM GLÚTEN? (Sim; Não; Tanto faz, não olho isso).

4) Você adquire um alimento quando identifica que ele NÃO CONTÉM GLÚTEN? (Sim; Não; Tanto faz, não olho isso)

5) Sob a perspectiva de saúde, qual a sua opinião sobre alimentos que contêm glúten?

6) O que você pensa de um alimento cujo o rótulo está escrito "NÃO CONTÉM GLÚTEN"?

7) Se você precisasse perder peso, você compraria alimentos com ou sem glúten? Por quê?

8) Você segue ou tem/teve vontade de seguir uma dieta sem glúten? Se sim, por quê?

9) Caso você siga uma dieta sem glúten: (Nunca abro uma exceção - sempre consumo alimentos SEM glúten; Às vezes abro uma exceção e consumo alimentos COM glúten; Muitas vezes abro uma exceção e consumo alimentos COM glúten).

10) Onde você obteve informações sobre o glúten? Pode assinalar mais de uma alternativa. (Profissional da saúde; Redes sociais; Internet; Televisão; Livros; Nenhuma das anteriores).

10.1) Caso tenha assinalado "nenhuma das anteriores" na questão 10, por gentileza, especifique. 


\section{Apêndice III. Folder virtual}
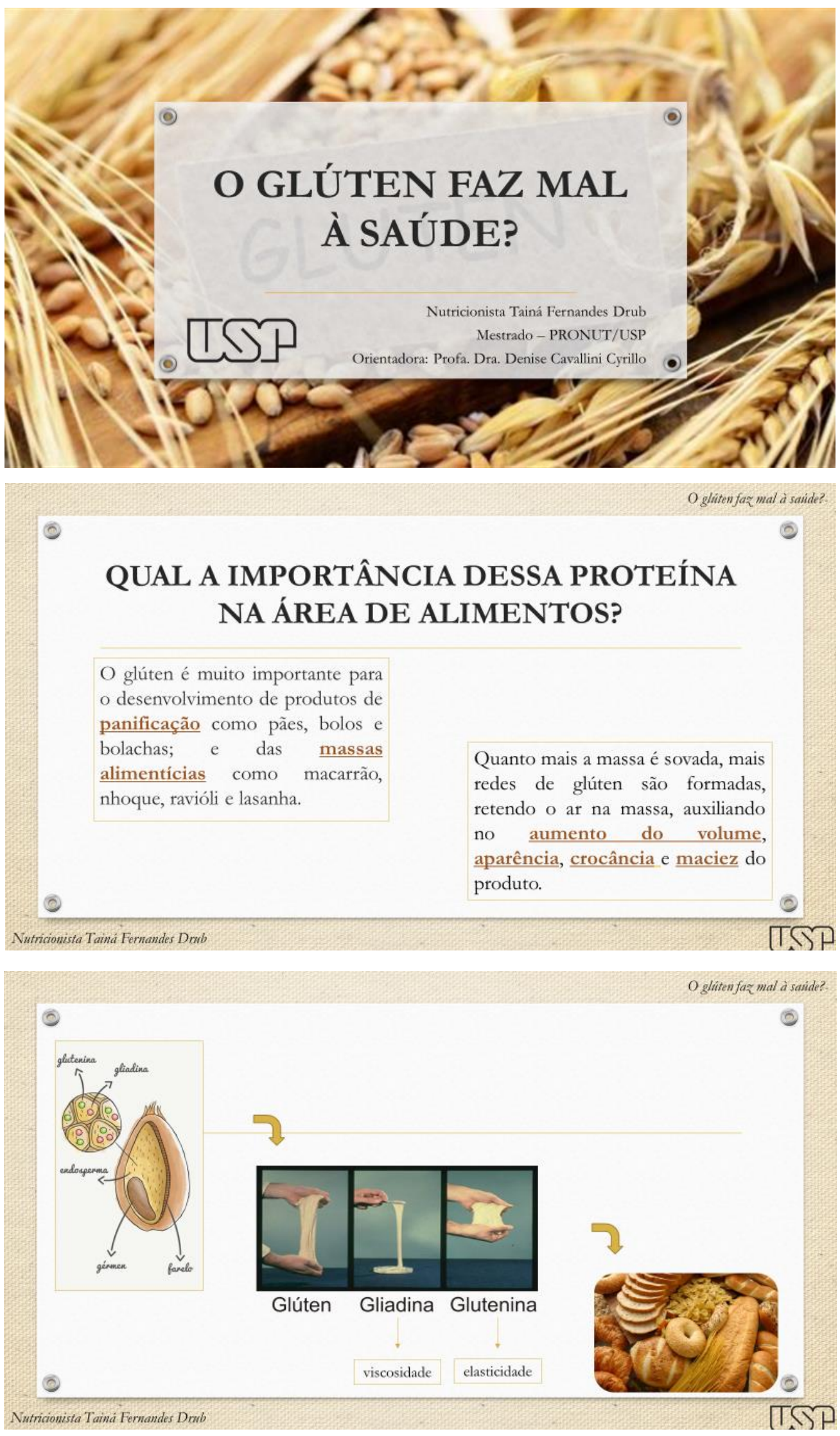

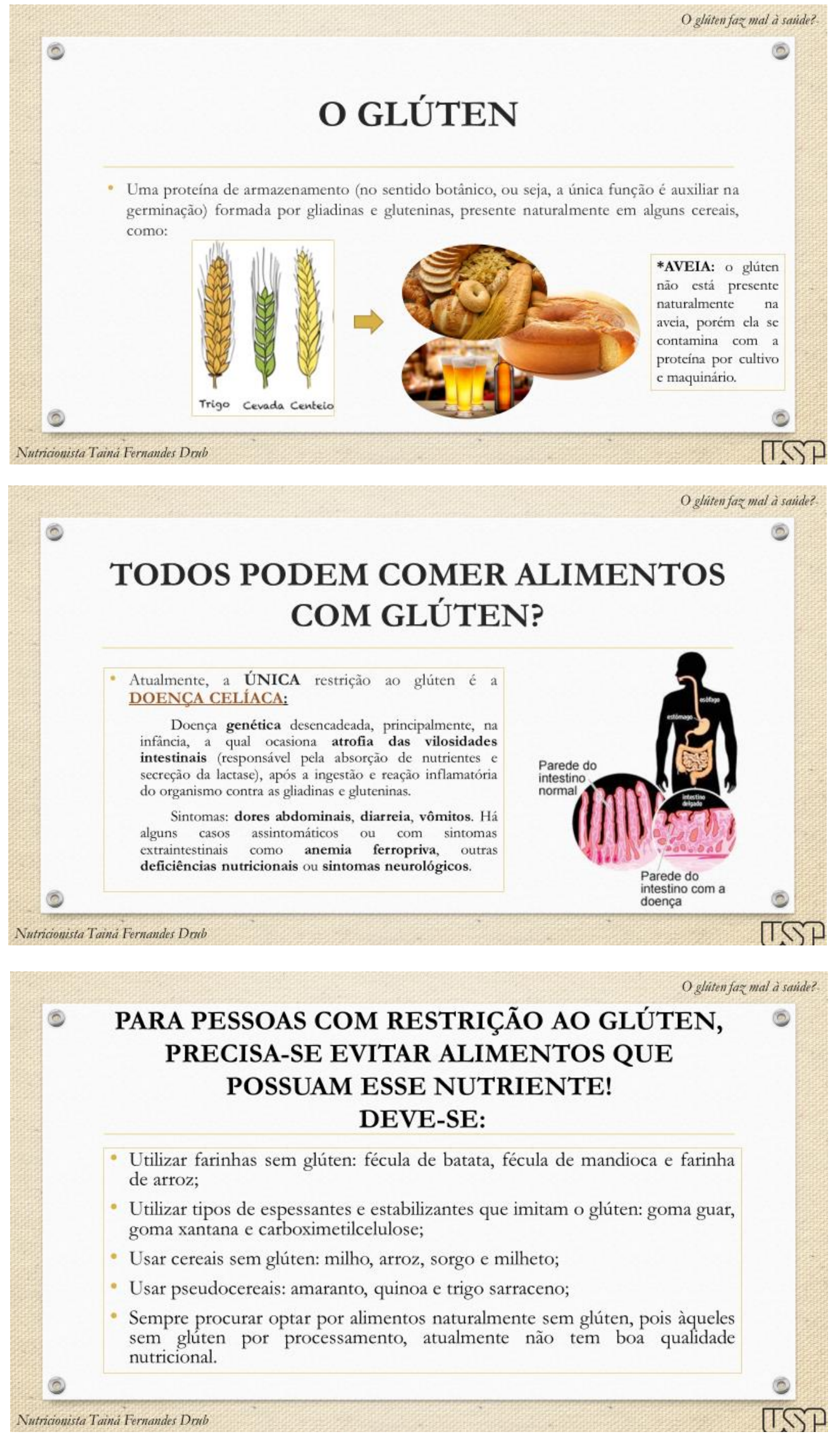


\section{ENTÃO O GLÚTEN NÃO FAZ MAL PARA A SAÚDE?}

O glúten é apenas uma proteína, que não tem valor biológico importante no organismo humano, contudo é inflamatório e faz muito mal APENAS a indivíduos que tem a doença celíaca!

\section{MAS POR QUE AS PESSOAS FALAM QUE O GLÚTEN FAZ MAL?}

\section{Sensibilidade ao Glúten Não Celíaca:}

Algumas pessoas relatam indisposição ao ingerir alimentos com glúten, mas estudos recentes mostram que o desconforto não é causado pelo glúten, mas sim, por alguns tipos de carboidratos, chamados de frutanos, que não são digeríveis e podem ser fermentados pela microbiota intestinal causando desconforto intestinal.

\section{Alergia ao Trigo:}

Não há necessidade de restrição ao glúten, e sim a alimentos que contenham trigo, pois a reação imunológica do organismo acontece contra outras proteinas do trigo.

(c)

\section{O GLÚTEN ENGORDA?}

- Não! E a retirada do glúten não leva a perda de peso!

- O que explica a redução de peso em alguns indivíduos que deixam de comer alimentos com glúten é a diminuição da ingestão de carboidratos e do valor calórico que costumam ser altos nestes alimentos (pães, bolos, bolachas, cerveja e massas alimentícias). 
(당

\section{VIVA UMA VIDA SAUDÁVEL!}

1) Faça pelo menos 3 refeições (café-da-manhã, almoço e jantar) e 2 lanches saudáveis por dia. Nào pule as refeições.

2) Inclua diariamente 6 porções do grupo do cereais (arroz, milho, trigo, pães e massas), tubérculos como as batatas e raízes como a mandioca nas refeições. Dê preferência aos grãos integrais e aos alimentos na sua forma mais natural.

3) Coma diariamente pelo menos 3 porções de legumes e verduras como parte das refeições e 3 porções ou mais de frutas nas sobremesas e lanches.

4) Coma feijão com arroz todos os dias ou, pelo menos, 5 vezes por semana. Esse prato brasileiro é uma combinação completa de proteínas e bom para a saúde.

5) Consuma diariamente 3 porções de leite e derivados e 1 porção de carnes, aves, peixes ou ovos. Retirar a gordura aparente das carnes e a pele das aves antes da preparação torna esses alimentos mais saudáveis!

\section{VIVA UMA VIDA SAUDÁVEL!}

6) Consuma, no máximo, 1 porção por dia de óleos vegetais, azeite, manteiga ou margarina.

7) Evite refrigerantes e sucos industrializados, bolos, biscoitos doces e recheados, sobremesas e outras guloseimas como regra da alimentação.

8) Diminua a quantidade de sal na comida e retire o saleiro da mesa.

9) Beba pelo menos 2 litros ( 6 a 8 copos) de água por dia. Dê preferência ao consumo de água nos intervalos das refeições.

10) Torne sua vida mais saudável. Pratique pelo menos 30 minutos de atividade física todos os dias e evite as bebidas alcoólicas e o fumo.

Fonte: Ministério da Sańde.

(9)

\section{REFERÊNCIAS}

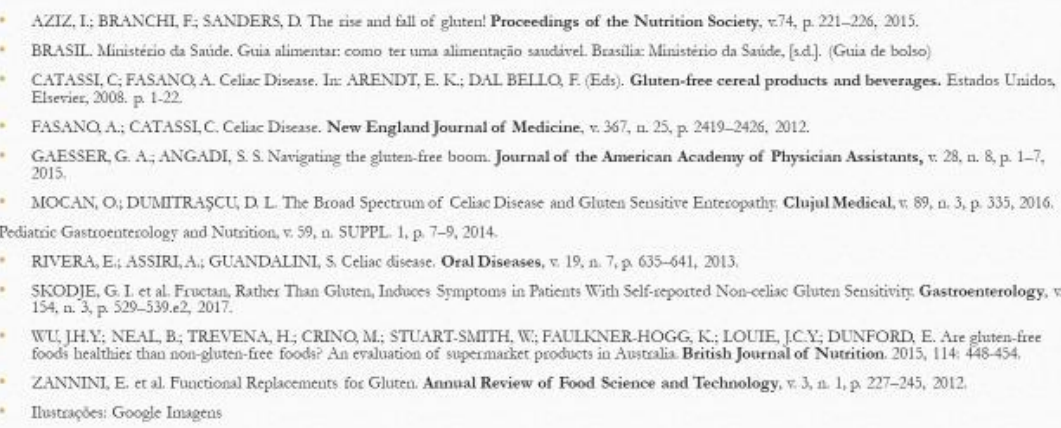




\section{OBRIGADA POR SUA} PARTICIPAÇÃO. SAÚDE!

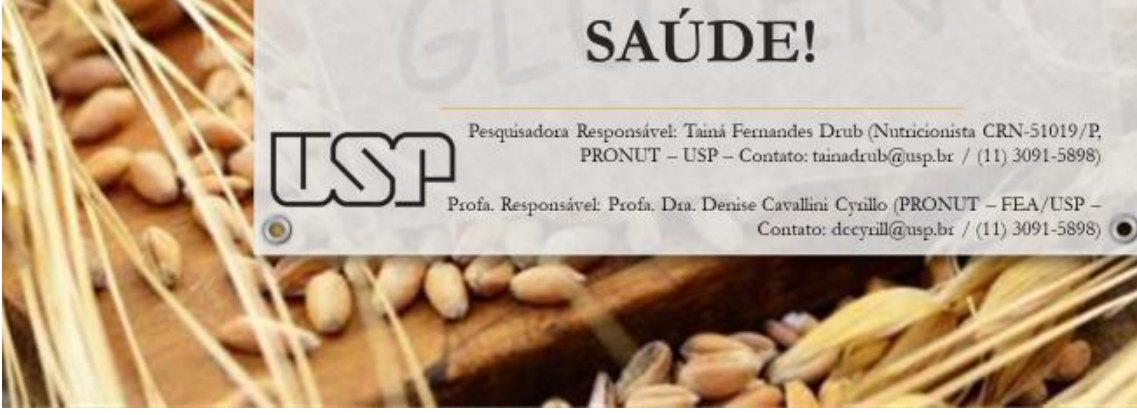




\section{Apêndice IV - Informações para publicação do artigo}

REVISTA: British Journal of Nutrition (ISSN 0007-1145)

FATOR DE IMPACTO: 3.302

\section{CLASSIFICAÇÃO QUALIS: A1}

RAZÃO DA ESCOLHA: Artigos da mesma natureza.

INSTRUÇÕES AOS AUTORES: https://www.cambridge.org/core/journals/britishjournal-of-nutrition/information/instructions-contributors

TÍTULO: A percepção dos consumidores brasileiros sobre a dieta sem glúten narrada pelo Discurso do Sujeito Coletivo / Brazilian consumer's perception of gluten-free diet narrated by Collective Subject Discourse

\section{RESUMO:}

A demanda de produtos sem glúten aumenta a cada dia não apenas pelo aumento de casos diagnosticados de doença celíaca, mas também por modismos difundidos em larga medida pelo marketing nutricional virtual que estimula a adoção de dietas livres de glúten com base em mitos relativos a malefícios gerados pelo glúten bem como para o ganho de peso e perda de qualidade de vida. O objetivo deste artigo é apresentar a percepção de consumidores acerca da dieta sem glúten por meio de uma investigação qualitativa baseada na técnica do Discurso do Sujeito Coletivo. Entre os principais resultados destaca-se o fato de que indivíduos, mesmo que sem doença celíaca, alegam estar fazendo a melhor escolha alimentar, baseados em informações sem embasamento científico extraídas da internet, desconsiderando ainda que os produtos sem glúten industrializados possuem baixa qualidade nutricional, sendo ricos em carboidratos, com elevada densidade energética e sódio, e preços bem mais altos do que que seus similares tradicionais. Políticas de otimização da informação nos meios midiáticos podem ser criadas a fim de incentivar o consumidor a fazer escolhas mais bem informadas, junto a órgãos influenciadores e reguladores como Agência Nacional de Vigilância Sanitária, o Conselho Federal de Nutricionistas e a Federação Nacional das Associações de Celíacos do Brasil.

Palavras-chave: produtos sem glúten; marketing nutricional virtual; rótulo de alimentos 


\begin{abstract}
:
Demand for gluten-free products is increasing everyday not only by the rise in diagnosed cases of celiac disease, but also by fads widespread largely through virtual nutritional marketing that encourages the adoption of gluten-free diets based on myths related to harm generated. by gluten as well as for weight gain and loss of quality of life. The aim of this paper is to present consumer's perceptions about gluten free diet through a qualitative investigation based on the Collective Subject Discourse technique. Among the main results is the fact that individuals, even without celiac disease, claim to be making the best food choice, based on unscientific information extracted from the internet, disregarding that gluten-free processed products have poor nutritional quality, being high in carbohydrates, with high caloric density and sodium, and far higher prices than their traditional counterparts. Information optimization policies in the media can be created to encourage consumers to make the right choices with influential and regulatory institutes such as the Agência Nacional de Vigilância Sanitária (ANVISA), the Federal Council of Nutritionists and the National Federation of Celiac Associations in Brazil.
\end{abstract}

Keywords: gluten free products; virtual nutritional marketing; food labels.

INTRODUÇÃO: Mesclar a introdução do artigo com o embasamento teórico.

METODOLOGIA: Colocar metodologia em etapas pertinentes a este estudo.

RESULTADOS: Colocar como resultados apenas a análise do discurso do sujeito coletivo.

DISCUSSÃO: Colocar a discussão completa e finalizar com a conclusão.

FINANCIAMENTO: O presente trabalho foi realizado com o apoio da Coordenação de Aperfeiçoamento de Pessoal de Nível Superior - Brasil (CAPES) - Código de Financiamento 001, com a concessão de uma bolsa de mestrado à discente.

AGRADECIMENTOS: Colocar os agradecimentos do trabalho de forma resumida.

CONFLITO DE INTERESSES: Declaro não haver conflito de interesses.

REFERÊECIAS: Alterar para Vancouver. 